IZA DP No. 7580

Doing Well in Reforming the Labour Market?

Recent Trends in Job Stability and Wages in Germany

Gianna C. Giannelli

Ursula Jaenichen

Thomas Rothe

August 2013 


\title{
Doing Well in Reforming the Labour Market? Recent Trends in Job Stability and Wages in Germany
}

\author{
Gianna C. Giannelli \\ University of Florence \\ and IZA \\ Ursula Jaenichen \\ $I A B$, Nuremberg \\ Thomas Rothe \\ $I A B$, Nuremberg \\ Discussion Paper No. 7580 \\ August 2013 \\ IZA \\ P.O. Box 7240 \\ 53072 Bonn \\ Germany \\ Phone: +49-228-3894-0 \\ Fax: +49-228-3894-180 \\ E-mail: iza@iza.org
}

Any opinions expressed here are those of the author(s) and not those of IZA. Research published in this series may include views on policy, but the institute itself takes no institutional policy positions. The IZA research network is committed to the IZA Guiding Principles of Research Integrity.

The Institute for the Study of Labor (IZA) in Bonn is a local and virtual international research center and a place of communication between science, politics and business. IZA is an independent nonprofit organization supported by Deutsche Post Foundation. The center is associated with the University of Bonn and offers a stimulating research environment through its international network, workshops and conferences, data service, project support, research visits and doctoral program. IZA engages in (i) original and internationally competitive research in all fields of labor economics, (ii) development of policy concepts, and (iii) dissemination of research results and concepts to the interested public.

IZA Discussion Papers often represent preliminary work and are circulated to encourage discussion. Citation of such a paper should account for its provisional character. A revised version may be available directly from the author. 


\section{ABSTRACT}

\section{Doing Well in Reforming the Labour Market? Recent Trends in Job Stability and Wages in Germany*}

The German "employment miracle", with a weak decline in employment and low unemployment during the great recession, seems to be a good example for a successful labour market reform. Nevertheless, there are concerns about rising inequality in the labour market. In this paper we analyze the quality of newly started jobs between 1998 and 2010 using a huge administrative data set which allows us to look at job durations and earnings for different groups of workers. We discuss changes in the distributions of job durations and earnings over time, and present microeconometric models controlling for individual, firm and regional characteristics. Our results show a fairly constant level of overall job stability, but decreasing real wages and rising wage dispersion over time.

\section{NON-TECHNICAL SUMMARY}

The Hartz reforms, implemented in the period from 2003 to 2005, were the most severe labour market reforms in Germany's post war history. We look at changes in job durations and wages over time in order to analyze whether the reforms have caused a decline in the quality of newly started jobs. Based on microdata, the results point to overall stable job durations for men and even somewhat longer durations for women. There are clearly shorter durations for groups of workers likely to be disadvantaged: temporary agency workers, unskilled workers and workers unemployed before the job. The analysis of the wage distributions shows both a decrease in real wages over time and an increase in overall wage dispersion. For selected groups of disadvantaged workers, evidence of disproportionate wage losses is found. In summary, the labour market reforms in Germany do not seem to have had a strong influence on job durations. With respect to wages, the Hartz reforms have conceivably reinforced an already existing tendency towards lower wages and greater wage inequality.

JEL Classification: $\quad \mathrm{C} 34, \mathrm{C} 41, \mathrm{~J} 31, \mathrm{~J} 62, \mathrm{~J} 68$

Keywords: labour market reforms, job quality, job duration, real wages, Germany, 1998-2010

Corresponding author:

Ursula Jaenichen

Institut für Arbeitsmarkt- und Berufsforschung

der Bundesagentur für Arbeit (IAB)

Regensburger Str. 104

90478 Nürnberg

Germany

E-mail: ursula.jaenichen@iab.de

\footnotetext{
*We wish to thank Johannes Ludsteck for making very helpful suggestions and comments.
} 
Career prospects of persons in marginal jobs and persons (re-)entering the labour market have now been a concern of labour market research and policy since at least two decades. In the 1980s and 1990s the German labour market was criticized for example by the OECD, because the strictness of employment protection legislation and the resulting restraints for firms to flexibly adjust labour input were seen as major causes for the persistence of unemployment and especially long-term unemployment.

After reforms of employment protection as well as reforms of the unemployment benefit system the labour market in Germany seems to perform surprisingly well. Three years after the reform of unemployment benefit (Hartz IV) in 2005 unemployment has decreased by one third. This is accompanied by a rise in employment of about the same size (1.5 million persons, see Graph 1). While transitions from unemployment to non-employment might have become more important because of e.g. stricter handling of sanctions in the employment agencies, there is some empirical evidence suggesting positive effects of the so called Hartz reforms on matching efficiency (Fahr/Sunde 2009; Klinger/Rothe 2012).

Graph 1: The Development of Employment and Unemployment in Germany, 1998 - 2010

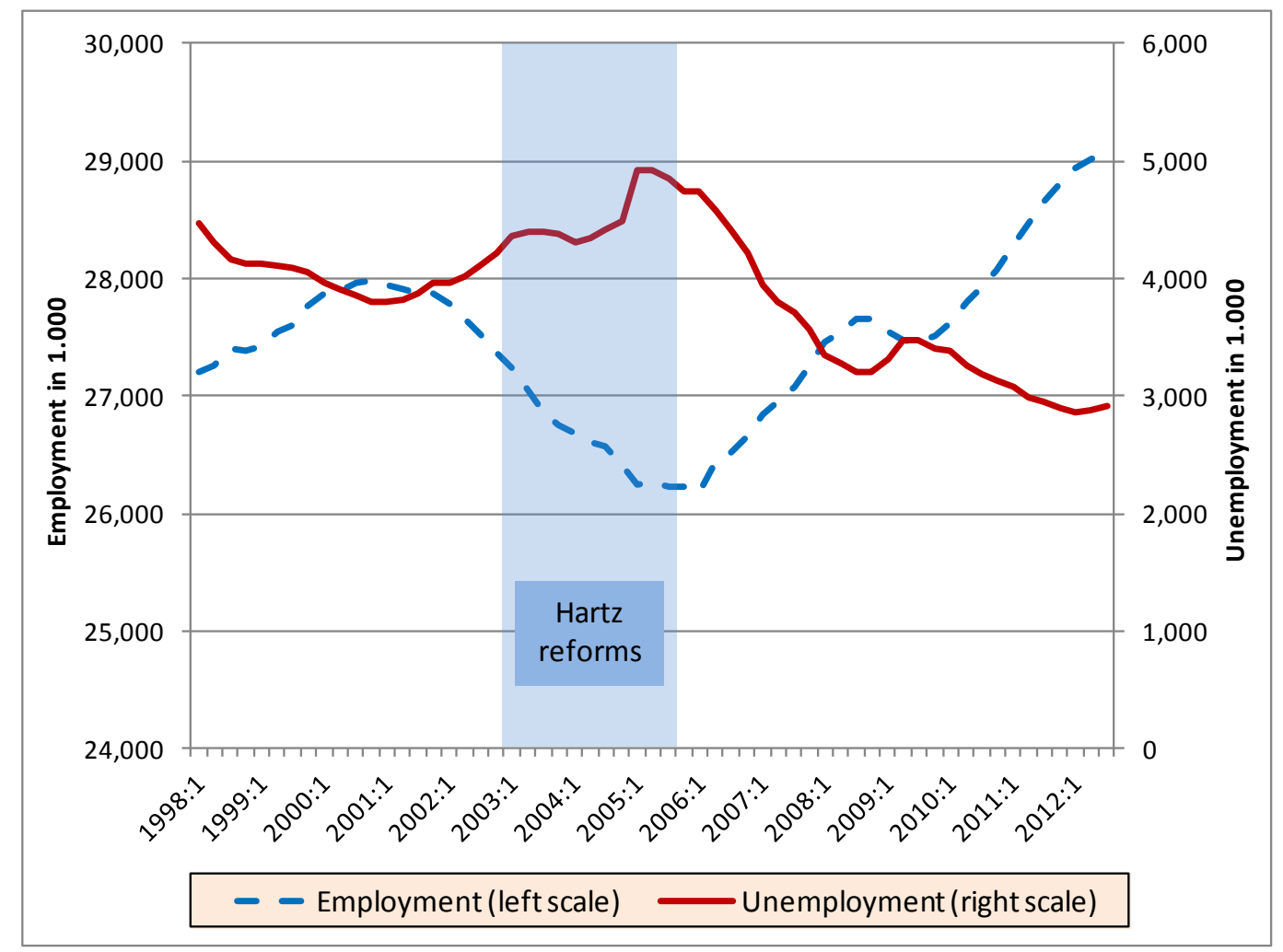

Source: German Federal Employment Agency, quarterly average of monthly data, seasonally adjusted.

With respect to the absence of stronger job losses during the great recession in 2008/2009, several explanations have been put forward. The most prominent is that this "employment 
miracle" has been caused by flexibilization via working time accounts and short-time work. Gartner and Merkl (2011) emphasize the importance of wage moderation in the years before the great recession for the German employment miracle. "The German Hartz reforms, which made the unemployment benefit system less generous, were certainly one of the reasons for the wage moderation" (Gartner/Merkl 2011). Another argument is one of changes in firm's hiring behaviour already during the upswing preceding the great recession (Burda/Hunt 2011). Möller (2010) argues that the crisis mainly affected export-oriented firms in the manufacturing sector in Germany. Because of difficulties to recruit qualified workers before the great recession, these firms tried to hold their workforce in order to avoid a loss of firm-specific human capital. The relatively high level of employment maintained during a strong recession possibly implies that in the last decade jobs have become more stable for a larger share of the work force despite the legal changes promoting flexibility in the labour market. This might also be caused by reforms of employment protection mainly addressing new working contracts without changing the level of protection for existing jobs, thus deepening labour market segmentation (Boeri 2011, 1199).

In this paper we study the "quality" of newly started jobs in the period from 1998 to 2010 . A job is defined as "new" if it implies employment with a new firm or - if in the same firm as before - a person has not been employed in that firm for at least three months. The durations of new jobs and the entry wages are used as indicators of job quality. In a first step, we discuss recent labour market reforms and illustrate the macro-performance of the German labour market during our observation period. In a second step, an overall analysis of trends in the distributions of job tenures and wages is performed on the basis of a large German administrative data set. The same data is used in the third step to develop multivariate models to assess changes in job tenures and wages during and after the periods of reforms. In the fourth step, trends in job quality are assessed for groups of workers who can be expected to be disadvantaged in their labour market opportunities. The paper ends with conclusions.

\section{Recent labour market reforms}

Changes in labour market institutions e.g. as a result of labour market reforms may influence employment stability and worker flows. Recent reforms of the German labour market (so called Hartz reforms) were implemented in three yearly waves from 2003 to 2005 (for detailed information see Jacobi/Kluve 2007). The main idea of the reforms was to improve effectiveness and efficiency of labour market services and policy measures.

The first two reforms, Hartz I and II, started in 2003 and were targeted at activating the unemployed e.g. by implementing new start-up subsidies and placing them into labour market 
programs that promised to be more effective. The labour market was deregulated, for instance, concerning temporary agency work, fixed-term contracts and dismissal protection and parts of placement services were outsourced into the private sector.

The main issue of Hartz III in 2004 was the re-structuring of the Federal Employment Agency and its local employment offices with the aim of rising efficiency within the organization and improving service quality.

Hartz IV, implemented in 2005, was the most severe and most criticized reform. It combines the previously existing unemployment assistance and social assistance into one means-tested unemployment benefit type II. This benefit is paid as a lump sum amount corresponding to the subsistence level and is no more dependent on the former wage. Entitlement is conditional on the income of other household members as well. Savings and financial assets up to a certain amount have to be spent before getting the benefit. Both these innovations increase the costs of becoming and staying unemployed. In addition, the period of entitlement to the unemployment benefit type I was shortened.

The expected impact of a reduction of unemployment benefit is twofold. First, employed workers might try to hold their jobs and avoid quitting a job, if they are not very sure to get a better one. The decreasing labour-turnover rate during the reform period and the recession of 2008 and 2009 (see Graph 2) is at least partly a result of a growing anxiousness to become unemployed. The second aspect is a higher willingness to make concessions among unemployed workers. There is an increasing group of job applicants who are willing to accept worse working conditions, longer distances to work and even lower wages (see Rebien/Kettner 2011). A poor matching quality and hence shorter job durations might be a consequence.

For the purpose of this paper, mainly two effects of the Hartz reforms are expected. The deregulative elements of the first reforms should rise flexibility in the labour market and thus lower job stability. The potential decrease in reservation wages brought about by the Hartz-IVreform might lead to increasing competition for new jobs and thus a tendency towards lower wages.

\section{Evidence on labour turnover, job stability and wage inequality}

Despite the exceptional performance of the German labour market during and after the great recession, with stable employment and low unemployment, there is a debate on the quality of jobs that made the German "employment miracle" possible. We define job durations and earnings as indicators of job quality. Job duration is sometimes used to measure job quality in the literature (e.g. Kahn 2008). The longer a job lasts the better is the quality of that job. Again, the higher the wage is, the better the job. 
The overall trends in worker turnover do not point to a general reduction in the duration of employment relationships, see Graph 2. Moreover, the labour-turnover-rate declined after the economic expansion in 2000 and 2001 and during the implementation of the Hartz reforms and did not reach the level of 7 or 8 percent per quarter since then.

\section{Graph 2: Labour-Turnover-Rate over the Business Cycle}

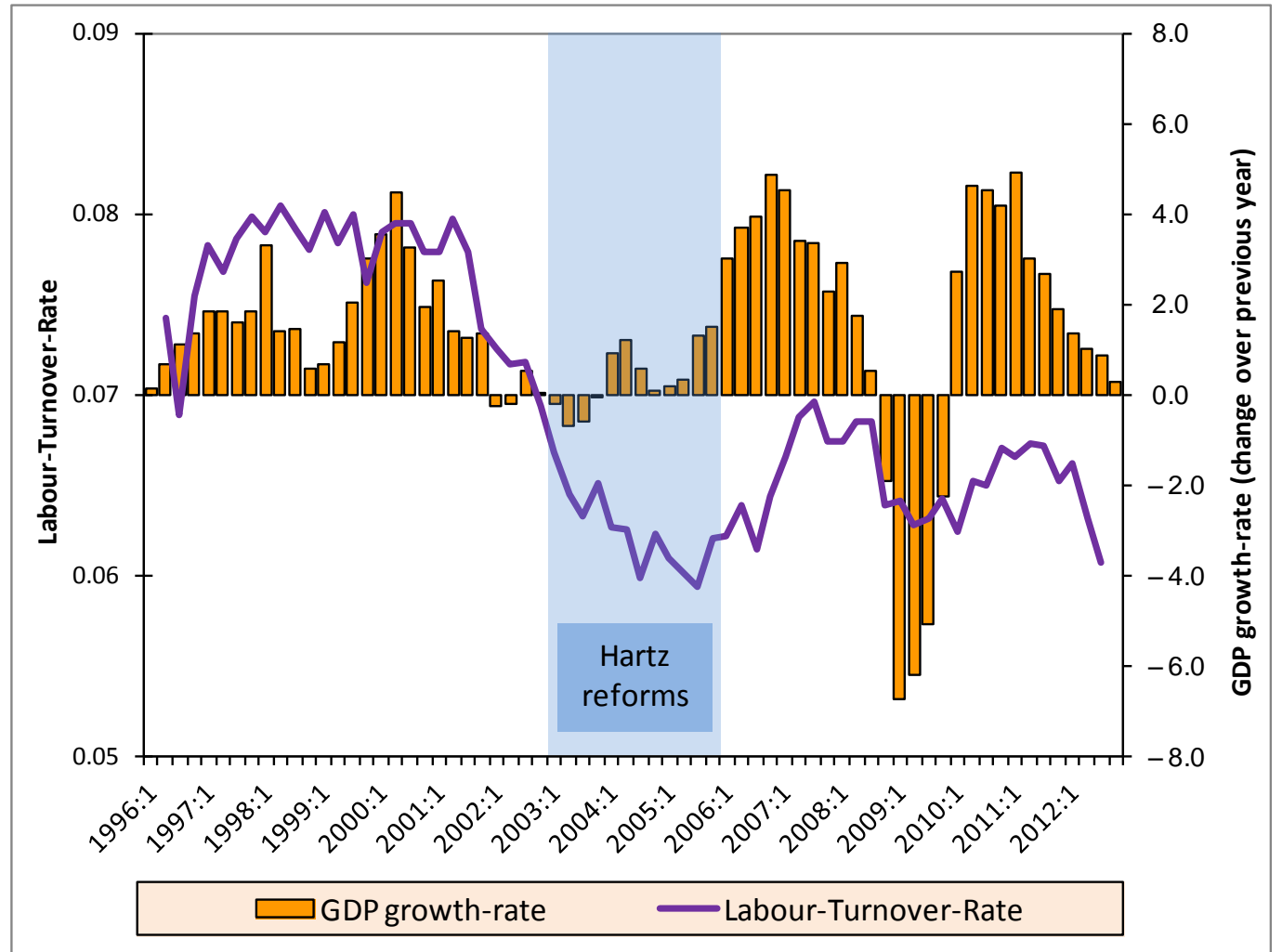

Source: Labour-Turnover-Rate, quarterly average of monthly data of the German Federal Employment Agency, GDP, quarterly data of the Federal Statistical Office, seasonally adjusted.

However, a high level of job stability does not apply for the workforce as a whole, as documented by the growing use of "atypical" working contracts like fixed-term work and temporary agency work (Konle-Seidl/Trübswetter 2011).

The existing literature on job duration in Germany shows that age, gender and skill level influence job stability (Bergemann/Mertens 2011; Boockmann/Steffes 2011). Boockmann/Steffes (2010) find that unemployed workers face a higher risk of unstable employment and shorter durations than workers changing from job-to-job. However, when firm heterogeneity is accounted for, the difference in job duration between both groups decreased, indicating that previously unemployed persons select into firms with low-duration jobs.

Giannelli, Jaenichen and Villosio (2011) analyze job and employment durations in Germany and Italy over a period of earlier labour market reforms. Concentrating on job entrants some evidence for a decrease in job stability is found. 
Business cycle effects on labour market transitions and job durations are also important. In general, re-employment as well as job-to-job transition rates are large and procyclical. In recent years the business cycle effect on re-employment and job-to-job transitions decreased (Schaffner 2011). The business cycle might have asymmetric effects: during a recession low skilled workers face a higher risk to lose their job, but they are however not the first to be hired in the following upswing, because employers have many options to choose from after the crisis, when unemployment is relatively high (Machin/Manning 1999: 3129f.).

As for the literature on wages in Germany, there are some recent studies looking at trends in the distribution of wages in Germany, all of them using the same administrative source as in our paper. Dustmann et al. (2009) focus on wages between 1975 and 2004 and ascertain a rise in wage inequality for Germany, starting in the 1980s and continuing since then. In the 1980s mainly the upper half of the wage distribution was affected, while in the early 1990s inequality started to rise also at the bottom half of the wage distribution. Their explanation of these findings is that in different periods skill-biased technological change, the decline in unionization and a change in the structure of skill supply contributed to the rise in inequality.

Riphahn/Schnitzlein (2011) look at wage inequality and long-term wage mobility in Germany. For West Germany, they present results from 1975 to 2008 and confirm the finding of greater wage inequality and especially a more recent decrease in real wages at the lower quantiles of the wage distribution. The comprehensive evidence on wage mobility points to a modest and more recent decrease in West Germany, together with a steady and substantial decline in wage mobility in East Germany since the early 1990s. Among others, changes in stability-related variables like employer change, unemployment experience and tenure are found as factors driving the changes in wage mobility.

The study of Card et al. (2013) is important because it highlights the contribution of establishments to wage inequality among fulltime workers. Again, the long-term trend towards rising wage inequality is demonstrated. Based on a linked firm-worker data sets constructed from the administrative employment data for Germany, additive fixed-effects models are estimated and a method of variance decomposition is applied. The authors find a large increase in the standard deviation of the individual-specific effect on wages and also in the dispersion of the establishment-specific wage component. Furthermore, assortativeness has increased, leading to individuals with higher potential wages being employed in establishments paying higher wages. 
The impact of the Hartz reforms on wages is analyzed by Arent and Nagl (2011). Exploiting the BA-Employment Panel $^{1}$, they estimate fixed-effects models containing a dummy variable which separates the observations into those before and those after year 2005. They find their hypothesis of a structural break in 2005 confirmed. Running separate regressions by region, gender, industry and skill the effect remains significant in most of the cases. In West Germany, but not in East Germany, wage losses are found to increase with the skill level.

\section{$4 \quad$ Data}

The microeconomic evidence presented in this paper is based on the German Integrated Employment Biographies (IEB), a large individual data set which is composed of various sources of administrative data and is regularly produced at the Institute for Employment Research (IAB) at Nuremberg. The population of the IEB consists of all employees subject to social security contributions, all recipients of unemployment benefits, job searchers, and participants in active labour market programmes of the Federal Employment Agency. A two percent sample of the IEB is used to look at new employment spells in West Germany beginning in the years from 1998 to $2010 .^{2}$

The information on individual work histories and on earnings stems from the firm's mandatory notifications to the social insurance agencies and contains start and end dates (exact to the day) of employment spells together with the amount of gross earnings during that spell. Spells without firm identifier as well as very short spells (less than three days) and spells with zero earnings reported are deleted. Job duration in our analysis is meant to be a period of employment with the same firm, possibly including a maximum of 90 days of interruption. In order to keep the observation window as long as possible, we allow for a maximum duration of 24 months, with longer job spells being censored. In the case of overlapping job spells, the spell with the highest amount of earnings is used. Spells will be shortened and right-censored, if they are interrupted by another spell having higher earnings. Spells are also declared as rightcensored if they are still ongoing after November 2010.

Earnings are top-coded which means that there is no information on the exact amount of earnings exceeding the threshold for social security contributions. This threshold is changing approximately every year and thus represents a maximum for observed earnings in that year. The observed amount of earnings is deflated with the official cost of living index to obtain real wages. A sort of lower threshold to wages is established by the so-called "mini-jobs", lowearnings jobs mostly exempted from social security contributions as well as other part-time

\footnotetext{
1 This data set is a scientific use file also based on the German employment statistics, prepared with the specific aim to facilitate data access to external researchers (outside the Federal Employment Agency and IAB).

2 See Jacobebbinghaus/Seth (2007) for a detailed description of an earlier version of the IEB-Sample (IEBS).
} 
jobs not liable to social security contributions. While the growth of such jobs in recent years (Jahn/Riphahn/Schnabel 2012) is certainly relevant to our research question, the fact that earnings from mini-jobs often serve as a kind of extra-income and are legally restricted to fall below a certain threshold (e.g. $400 €$ in year 2012) makes it difficult to include them in a general analysis of earnings. Thus, mini-jobs and low-earnings part-time jobs are excluded. As a further limitation, the data allow to distinguish full-time and part-time work, but do not contain information on hours worked. As a consequence we include part-timers (those liable to social insurance) in the analysis of job durations, but we exclude them from the earnings' analysis.

The ease or difficulty to find a new job after unemployment represents an important indicator of the success of labour market reforms. We use the information on episodes of registered unemployment and benefit receipt which is also contained in the IEB to distinguish jobs taken up after a period of unemployment from job-to-job changes (allowing for a maximum period of 31 days between jobs). As there are non-neglibile numbers of persons with "gaps" before the current employment, i.e. periods not contained as times of employment or unemployment in our data, these are specified as separate categories of the preceding labour market status.

With respect to the type of employment contract, the data do not identify fixed-term contracts. There is, however, a possibility to look at temporary agency workers, because these can be distinguished relatively well making use of the industry code (see Antoni/Jahn 2009). Industry as well as firm size are also used as control variables in both job duration and earnings analyses. Because of several changes in the classification system of industries, a combined 3digit industry variable generated at IAB's Research Data Center (see Eberle et al. 2011) is used and regrouped into broader categories for the regression analyses. To control for business cycle effects, information on regional GDP growth obtained from the German Federal States' Accounts (VGR der Länder) and the regional unemployment rate made available by Federal Statistical Office (destatis) is merged on the level of 326 districts (NUTS 3, Kreise). Seasonal effects are modeled by including dummy variables for the quarters of job entry.

The socio-economic information contained in the administrative data comprises age, gender, nationality as well as a broadly grouped variable on educational and occupational level. We exclude apprentices from the analysis. Because of a fairly high proportion of persons without information on education and skill, we include these missings as an extra category in our skill variable.Apart from the wage analyses being confined to full-time workers only, different sets of observations will be used for the two variables and in different analyses. The descriptive analyses for tenure include new job spells starting in the period from 1998-2009, while the descriptive wage analyses will use spells beginning in the years 1998-2010. The multivariate 
analyses use a shortened observation window, with the reduction of the analysis period for job tenure being dictated by the availability of complete employment data only until the year 2009 . The multivariate analyses of wages end with spells starting in the year 2009 because not all of the covariates are available for the year 2010.

The evolution of job durations and earnings over time is assessed by looking at cohorts of job entrants in different years or periods. In the model analysis, three periods are distinguished: the years 1998 to 2002 form the period before the Hartz reforms, the years 2003 to 2005 constitute the reform period, and the remaining years until 2010 constitute the period after the reforms.

\section{$5 \quad$ Results}

\subsection{Trends in the distributions of job tenures and wages}

We adopt Kaplan-Meier survival function estimators to look at changes in the distribution of the durations of new jobs. To analyze entry wages, we compare quantiles of the distribution of $\log$ wages over time. Both steps are performed for new jobs distinguishing first by gender only, and thereafter having a look at subgroups distinguished further by age and skill level.

\subsubsection{Durations of newly started jobs}

Tenure is defined as an uninterrupted period of work with the same employer. Graph 3 shows the probabilities to stay in a job after 6,12, 18 and 24 months, for job spells starting between 1998 and 2009.

First of all we can note that job stability is pretty high. The 12-months-survival probabilities for male workers are between 50 and 60 percent, for female workers even higher (see Table A-1 in the appendix). Over time, the survival probabilities for male workers seem to be pretty stable, whereas for female workers there is a slight increase in survival probabilities, implying a tendency towards longer job durations over time. There is a temporary decrease in the survival probabilities for jobs beginning in the year 2000, more pronounced for women and longer durations. While we do not have a ready explanation, the size of the reduction in survival probabilities is limited (up to 4 percentage points for women's 24-months-survival probability, see Table A-1 in the appendix). ${ }^{3}$ Overall, the vertical distances between the survival probabilities at different durations remain fairly constant, meaning that within the groups of male and female workers job durations have not become much more unevenly distributed over time.

3 For longer durations, there is also a decrease in the 2009 survival probabilities. The reason might be that employment information is available until the end of 2010, thus many of the spells starting in 2009 are right-censored. 
Graph 3: Tenure of Workers in West Germany 1998-2009, Survival Probabilities by Gender after 6, 12, 18 and 24 months

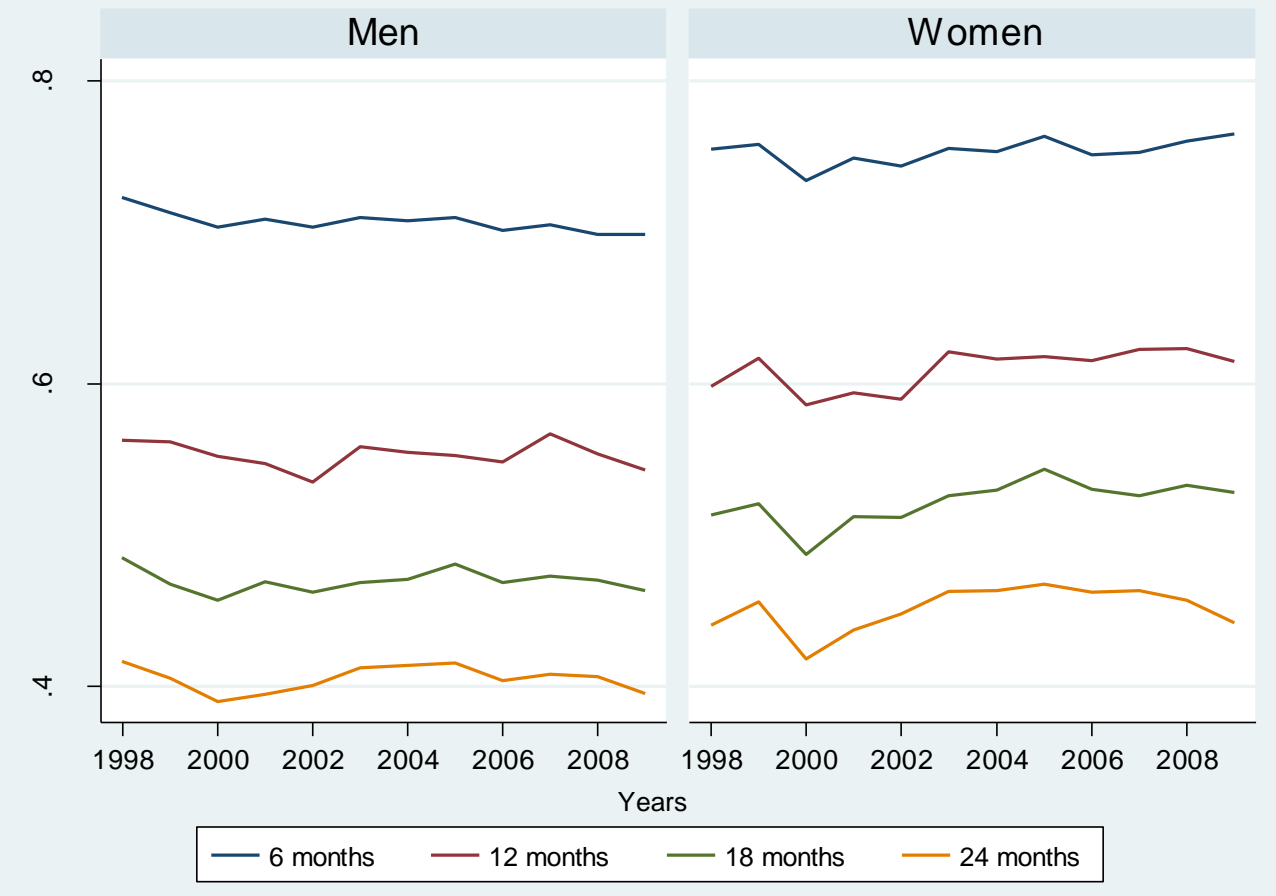

Source: IEB, own calculations, $\mathrm{N}=832.158$.

Graph 4: Tenure of Workers in West Germany 1998-2009, Survival Probabilities by Gender, Age and Skill after 6, 12, 18 and 24 months
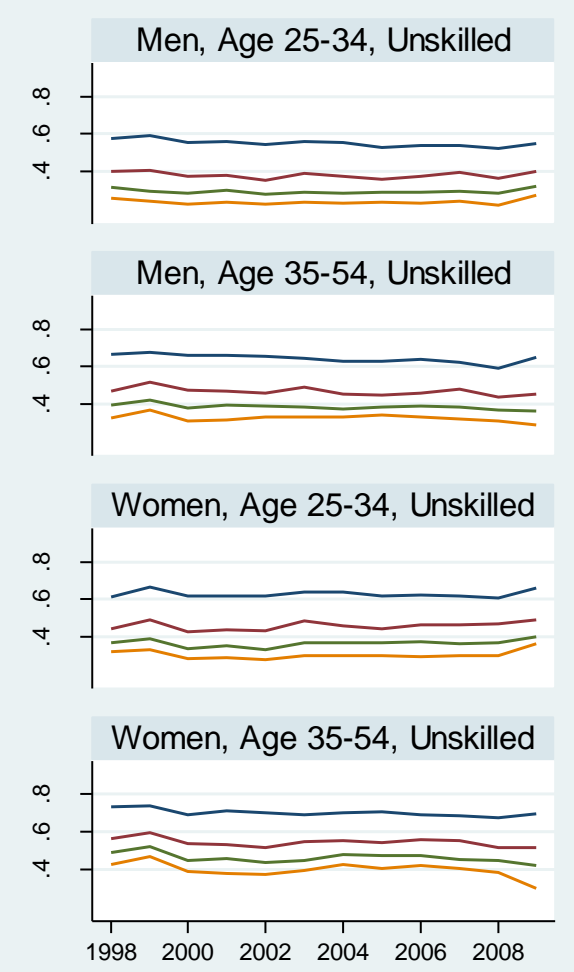

$$
\begin{gathered}
\text { Years } \\
-6 \text { months }-12 \text { months }-18 \text { months }
\end{gathered}
$$

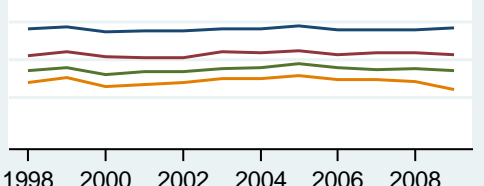

Men, Age 25-34, High-Skilled

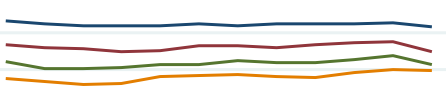

Men, Age 35-54, High-Skilled

Men, Age 35-54, Skilled

Women, Age 25-34, Skilled

Women, Age 25-34, High-Skilled

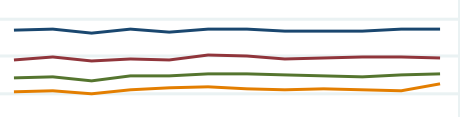

Women, Age 35-54, Skilled

Women, Age 35-54, High-Skilled

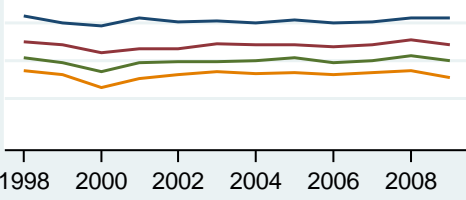

$\begin{array}{llllll}1998 & 2000 & 2002 & 2004 \quad 2006 \quad 2008\end{array}$

Source: IEB, own calculations, N=832.158. 
Graph 4 distinguishes further between two broad age groups (25-34 years and 35-54 years) and three skill categories (see also Table A-2 in the appendix). The first, "unskilled", comprises workers with lacking skill information as well as workers with lower than medium education and without vocational training. The category "skilled" consists of workers with up to medium education, workers with vocational training and workers with a level of education qualifying for professional college or university attendance. Workers in the last category, "high-skilled", own a degree from college or university.

We see a positive effect of the skill level for men and women, with the difference between skilled and high-skilled female workers being rather small, however. For no group, a clear tendency towards shorter job durations after the Hartz reforms is observed. Furthermore, within groups, the survival probabilities at 6, 12, 18 and 24 months again seem to run fairly parallel, thus giving no clear hints of growing inequality with respect to job durations.

\subsubsection{Wages in newly started jobs}

Wages are analyzed for full-time workers only, because no information on hours worked is available from our data. The wage variable is measured as log real wages in prices of 2005 . We first look at the $25^{\text {th }}$ percentile, the median and the $75^{\text {th }}$ percentile of the distributions for men

\section{Graph 5: Percentiles of the Wage Distribution for Fulltime Workers in West Germany, 1998-2010, by Gender}

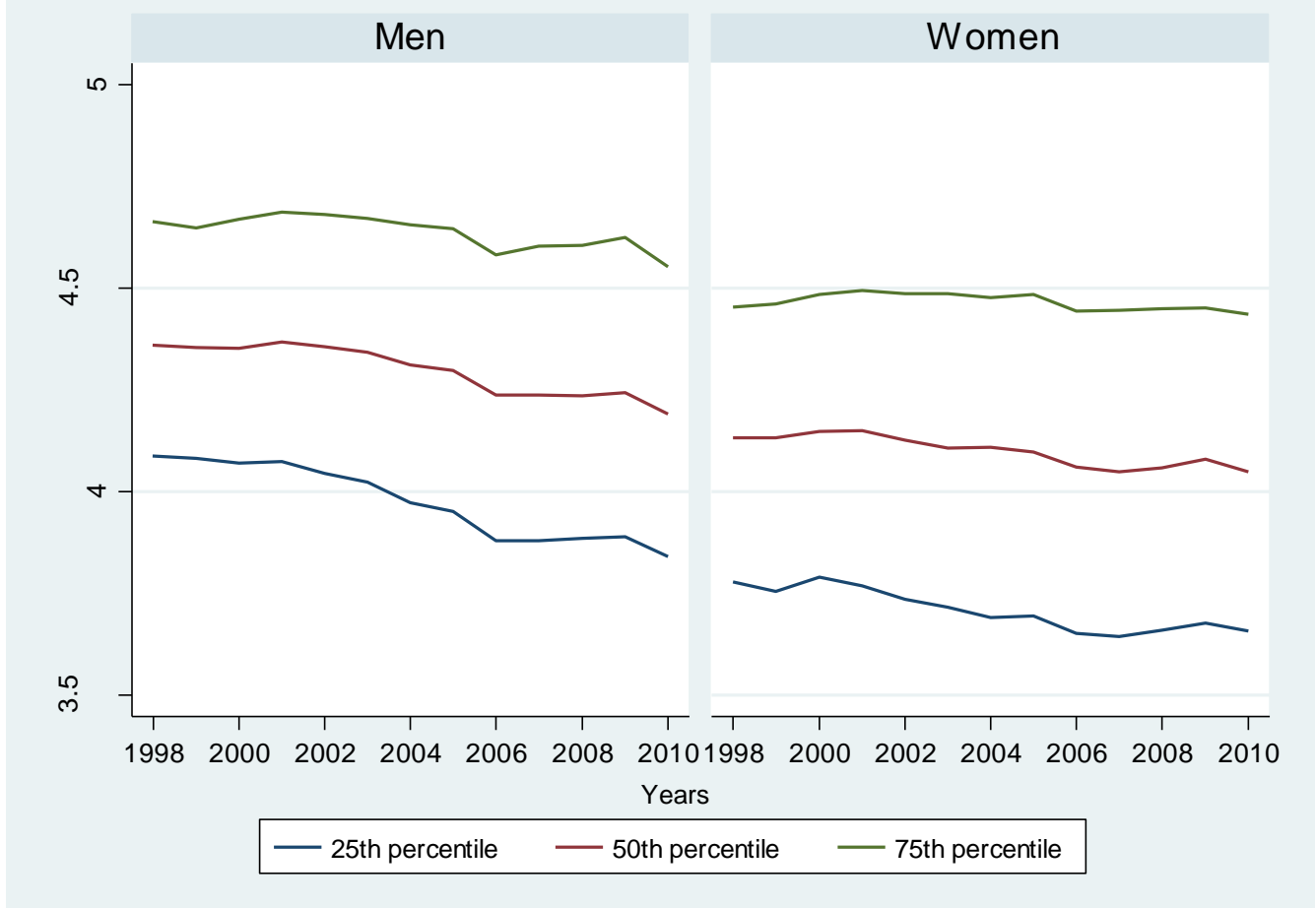

Source: IEB, own calculations, N=761.246.

and women in West Germany. The results are displayed in Graph 5, the exact figures for the first and the last year, 1998 and 2010, can be found in Table A-3 in the appendix. 
The decrease in real wages after the year 2001 is clearly visible. For both men and women, the decline in wages is strongest in the 25th and 50th percentile of the wage distribution, the decline in the 75th percentiles is comparatively modest: Wage inequality has been rising for men and for women. The lower interquartile difference (50th percentile minus 25th percentile) has increased by $8 \mathrm{log}$ points for men compared to $4 \log$ points for women, the higher interquartile difference (75th percentile minus 50th percentile) has increased by 6 log points both for men and women (Table A-3).

As already noted, "wage moderation" is one potential explanation of Germany's relatively good employment performance during the "great" recession 2008/2009. The results show, in accordance with most of the other studies ${ }^{4}$ summarized in section 3 , that the decrease in real wages initiates well before the Hartz reforms. Thus the role of the reforms might have been to reinforce the already existing tendency to lower wages, but not to cause it.

\section{Graph 6: Percentiles of the Wage Distribution for Fulltime Workers in West Germany, 1998-2010, by Gender, Age and Skill}

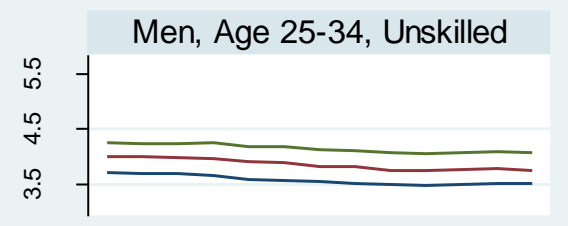

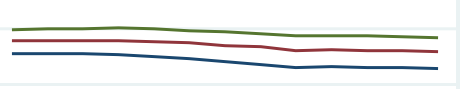
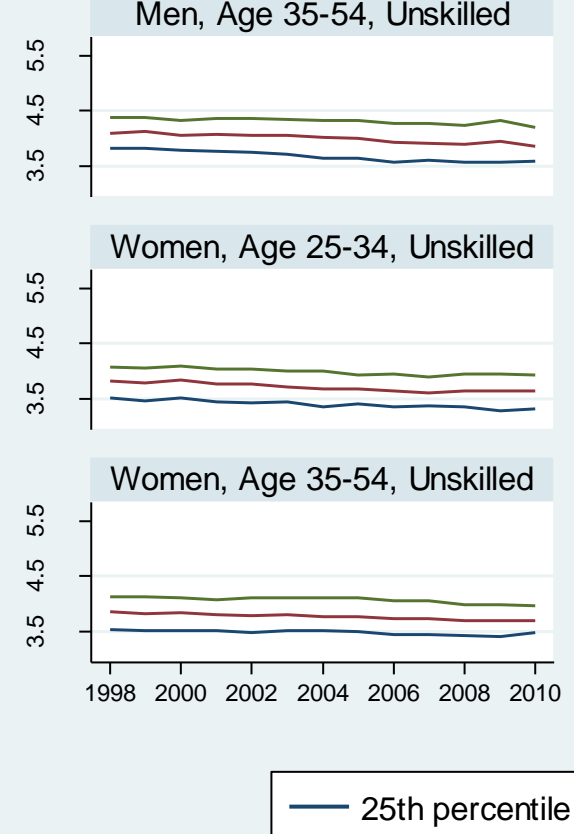

Men, Age 35-54, Skilled

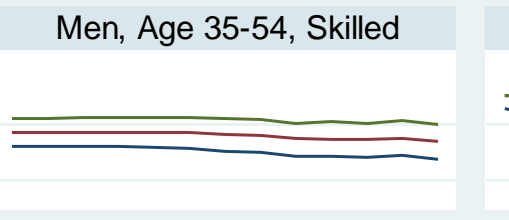

Women, Age 25-34, Skilled

Women, Age 25-34, High-Skilled

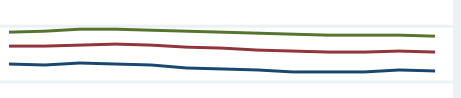

Women, Age 35-54, Skilled

Women, Age 35-54, High-Skilled

Source: IEB, own calculations, $\mathrm{N}=761.246$.

4 The Arent/Nagl (2013) study gets different results on the timing as well as one the skill dimension of the decrease in wages after 2000. 
When we distinguish between two age groups and three skill groups (Graph 6, Table A-4 in the appendix), we find again a strong positive skill effect. There is also a gender effect with women's wages being lower for comparable age and skill groups. The group of high-skilled workers did not experience a similar decrease in real wages as have the other skill groups. The median log wage for high-skilled men in the higher age group, for example, decreased from 5,04 in 1998 to 4,98 in 2010, implying a wage loss of about 6 percent. The corresponding 1998-2010 median wage loss for unskilled men in this age group was about 14 log points and that for skilled men even $16 \log$ points (Table A-4) ${ }^{5}$. Within the groups of skilled and highskilled workers the decline in wages is yet stronger in the 25 th percentile (that is for workers with the lowest earnings in these groups) after 2002 or $2003 .{ }^{6}$ Compared to the overall analysis in graph 5, however, the trend towards rising wage dispersion seems to be less pronounced within groups. This observation implies that a changing composition of the work force with respect to age and skill has contributed to the overall increase in wage inequality.

\subsection{Modelling job duration and wages}

One purpose of the model analysis presented in the following is to demonstrate the effect of important covariates on job tenure and wages. The main focus, however, is on analyzing the evolution of job stability and wages across three periods: the years 1998 to 2002 (before the reforms), the years 2003 to 2005 (reform period), and the remaining years until 2008/2009 (after the reforms).

\subsubsection{Job duration models}

To analyze trends in job durations in a model framework, we estimate the following piecewise constant exponential mixed proportional hazard model (Blossfeld et al. 2007: ch. 5: Cameron/Trivedi, 2005: 591):

$$
\lambda_{i j}\left(t \mid x_{i} \beta, v_{i}\right)=\lambda_{0}(t) \exp \left(x_{i} \beta\right) v_{i} \quad i=1, \ldots, N ; j=1, \ldots, J
$$

and

$$
\lambda_{0}(t)=\lambda_{j}, \quad \tau_{j-1}<t<\tau_{j}
$$

$\lambda_{i j}$ is the hazard rate representing the risk of leaving the current employer for individual $i$ during the $j^{\text {th }}$ time interval. Job durations are splitted into at most $J$ time intervals (pieces) to model changes in the risk of job termination conditional on the time already spent on the

5 The differences in log points may be interpreted as percentage wage changes.

6 For male high-skilled workers, the 75th percentile unfortunately is not informative, as for this group more than a quarter has entry wages above the social security threshold. 
current job. The $j^{\text {th }}$ interval starts at duration $\tau_{j-1}$ and ends at duration $\tau_{j}$. The baseline hazard $\lambda_{0}(t)$ is a step function which is constant within intervals.

The vector $x_{i}$ is a set of individual, firm and macroeconomic time invariant explanatory variables which are specific of the individual at the beginning of the job. The model also includes a gamma-distributed error term $v_{i}$ to allow for unobserved heterogeneity. The proportional hazard property implies that the ratio of any two individual hazard rates is constant along the job durations of these two individuals. The model is similar to the job stability model presented in Giannelli et al. (2011), however estimated for a later time period and including also jobs taken up later in the career, while the former only looked at labour market entrants. It is a single spell model, thus for persons with more than one new job in the observation window, one spell is randomly selected. We include tenure spells with starting dates until 2008, to make sure that longer durations are observed also for the most recent job entries. The model is estimated separately for men and women in West Germany.

The estimated effects of the covariates on employment stability are presented in the form of hazard ratios (see Table 1). For binary and categorical variables, hazard ratios give the quotient of the hazard rates of the actual group and the reference group. A value of the hazard ratio greater than 1 implies a positive effect on the risk of leaving the job and a negative effect on duration for that variable. Values smaller than 1 imply a reducing effect on the hazard rate and thus a positive or prolonging effect on job duration.

The pattern of the estimated risk of leaving a job is non-monotone: the hazard ratios for the time pieces at the top of the table are first slightly increasing and then start to decrease after the first $4^{\text {th }}$ months of employment.

The estimated hazard ratios for the time period indicators (year of entry) are of central interest: they are smaller than one for both men and women during the reform period (2003 to 2005). For the post-reform period (2006 to 2008), the hazard ratio continues to be smaller than one for women, but is insignificant for men. These results imply that job tenures ceteris paribus are somewhat longer for new jobs started in the reform period (2003 to 2005) compared to the reference period (1998 to 2002). For men, in the years after the Hartz reforms, durations are not different from those in the reference period, while for women, job durations continue to be slightly higher than in the period preceding the Hartz reforms. 
Table 1: Duration Models for West Germany, New Jobs 1998-2008, by Gender

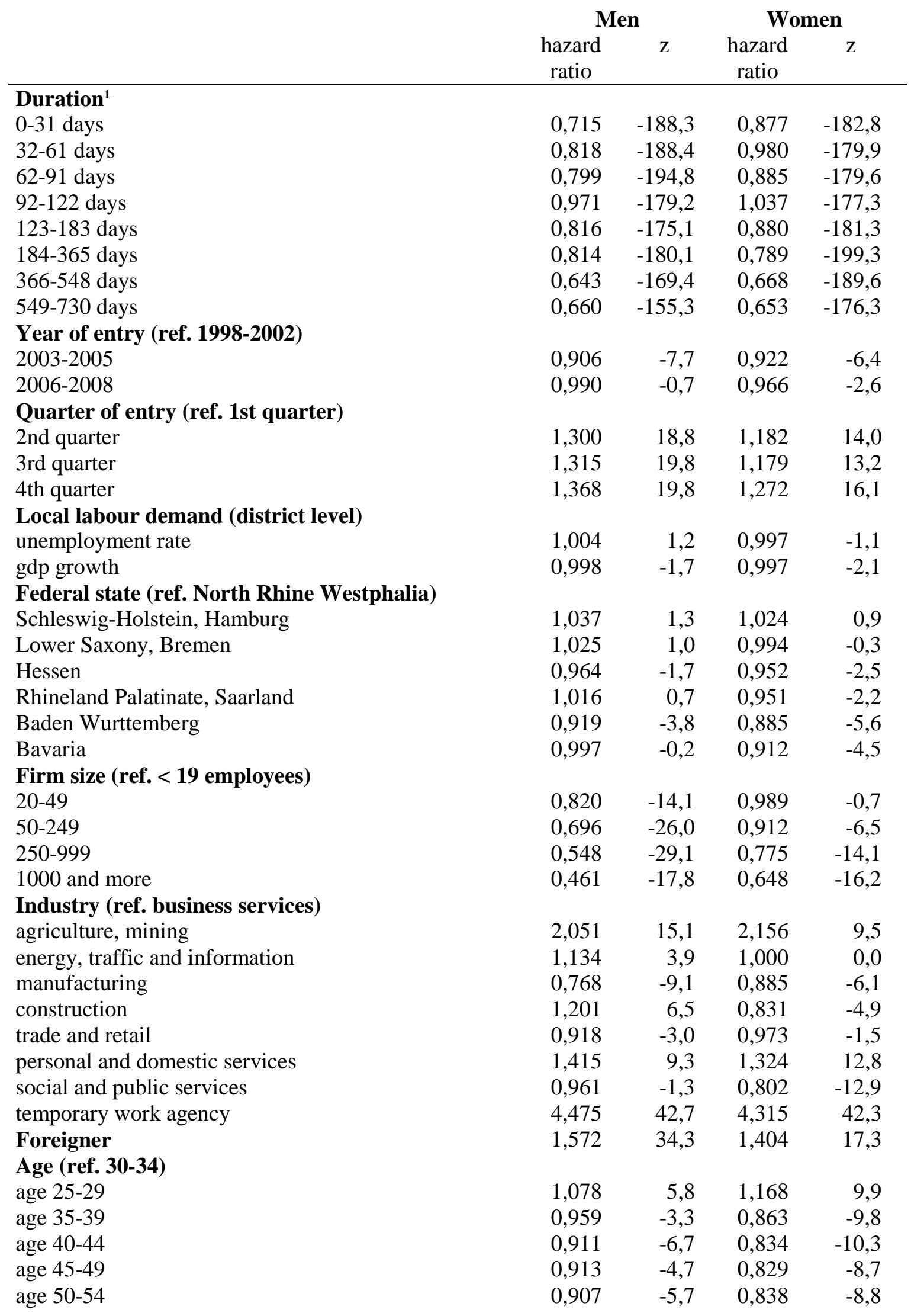


Table 1 continued

\begin{tabular}{|c|c|c|c|c|}
\hline & \multicolumn{2}{|c|}{ Men } & \multicolumn{2}{|c|}{ Women } \\
\hline & $\begin{array}{c}\text { hazard } \\
\text { ratio }\end{array}$ & $\mathrm{z}$ & $\begin{array}{l}\text { hazard } \\
\text { ratio }\end{array}$ & $\mathrm{z}$ \\
\hline \multicolumn{5}{|c|}{ Skill level (ref. vocational training with at most intermediate degree) } \\
\hline missing information on educational level & 1,371 & 10,9 & 1,404 & 10,0 \\
\hline no vocational training with at most intermediate degree & 1,242 & 12,9 & 1,248 & 12,8 \\
\hline Abitur/equivalent; with or without vocational training & 1,078 & 3,9 & 1,063 & 4,1 \\
\hline university/technical/professional college degree & 0,790 & $-13,5$ & 1,046 & 2,8 \\
\hline \multicolumn{5}{|l|}{ Preceding state (ref. job-to-job) } \\
\hline first spell & 1,825 & 27,2 & 1,601 & 17,5 \\
\hline unemployed & 2,226 & 47,0 & 1,880 & 37,2 \\
\hline job followed by gap & 1,585 & 31,2 & 1,411 & 23,8 \\
\hline unemployment followed by gap & 1,665 & 28,0 & 1,498 & 21,4 \\
\hline Part-time (min. 18h/week) & 1,406 & 13,1 & 0,956 & $-3,4$ \\
\hline Variance of frailty term $(\log \theta)$ & $-0,285$ & $-9,3$ & $-0,596$ & $-8,5$ \\
\hline Wald chi' ${ }^{2}$ & \multicolumn{2}{|c|}{1.390 .753} & \multicolumn{2}{|c|}{1.368 .533} \\
\hline Log pseudolikelihood & \multicolumn{2}{|c|}{-216.167} & \multicolumn{2}{|c|}{-170.835} \\
\hline Number of obs. & \multicolumn{2}{|c|}{180.369} & \multicolumn{2}{|c|}{142.095} \\
\hline
\end{tabular}

In order to control for regional and seasonal influences we use dummy variables for the quarter of entry and for the West German federal states. Further indices of the local labour market like regional unemployment and gdp growth rate show only minimal effects on job stability. Firm size, however, has a strong influence. Job duration is monotonically increasing with the size of the firm, both for men and women.

We can also see fairly strong and significant effects for some industries. Jobs are most stable for men in manufacturing and for women in social and public services. By far the shortest job durations both for men and women are found for temporary agency jobs. Part-time jobs with a minimum of 18 hours per week are much shorter for men, but even a little more stable for women. Probably many of the men's part-time jobs are only temporary solutions until a fulltime job has been found.

Age and nationality have the expected effects: Job duration is much shorter for younger age groups and foreigners. The skill effect is pronounced for men and for women. The reference group "vocational training with at least intermediate degree" is characterized by long durations, only for men a university or comparable degree leads to more job stability.

There is a strong influence of the preceding labour market status on the duration of the current job. If persons have not been employed before taking up a new job, expected tenure is significantly shorter. The reference group, containing the largest number of persons, are job-to- 
job changes. All other groups clearly experience shorter job durations, with persons immediately unemployed (no gap) before the job having the worst expectation.

\subsubsection{Wage models}

To take the threshold for social security contributions into account, censored regression models are estimated (Cameron/Trivedi, 2005: 536-544).

Let the observed censored wage $W_{i j}$ of individual $i$ in year $j$ be the realization of a latent variable $W_{i j} *$ :

$$
W_{i j}^{*}=x_{i j}{ }^{\prime} \beta+\varepsilon_{i}
$$

$x_{i j}$ are the covariates of individual $i$ if her employment spell starts in year $j, \varepsilon_{i}$ is a normally distributed error term with variance $\sigma^{2}$.

The observed wage is

$$
W_{i j}=\left\{\begin{array}{lll}
W_{i j} * & & W_{i j} *<c_{j} \\
c_{j} & & W_{i j} * \geq c_{j}
\end{array}\right.
$$

$c_{j}$ is the threshold for social insurance contributions which varies over time, more or less every year.

The maximum likelihood estimation ${ }^{7}$ gives results for the vector of coefficients, $\beta$ as well as for the variance $\sigma^{2}$. The coefficients measure the influence of the covariates on the latent variable $W_{i j} *$. For binary variables, the coefficients can be interpreted as percentage deviations from the reference group's wages.

As in the tenure model, one randomly selected employment spell per person beginning in the period 1998 to 2009 is used for persons having more than one spell in our observation period. Also, the models are estimated separately for men and women in West Germany (see Table 2). Once again, the coefficients of the time period indicators are of central interest. They are negative for the reform period (2003-2005) as well as for the period after the Hartz Reforms (2006-2009), thus real wages have been falling since the reference period. The negative wage effect is stronger in the post-reform period and it is also stronger for women than for men. The skill effect goes in the expected direction. Potential work experience has a significant effect only for men. The wages of foreigners are 5 percent lower for women and even 12 percent lower for men. The preceding labour market status is of high relevance also for wages in newly

7 We use the STATA routine "intreg" for estimation. 
Table 2: Wage Models for West Germany, New Fulltime Jobs 1998-2008, by Gender

\begin{tabular}{|c|c|c|c|c|}
\hline & \multicolumn{2}{|c|}{ Men } & \multicolumn{2}{|c|}{ Women } \\
\hline & coefficient & $\mathrm{z}$ & coefficient & $\mathrm{z}$ \\
\hline \multicolumn{5}{|l|}{ Year of entry (ref. 1998-2002) } \\
\hline 2003-2005 & $-0,020$ & $-5,1$ & $-0,033$ & $-6,5$ \\
\hline 2006-2009 & $-0,083$ & $-27,1$ & $-0,088$ & $-23,7$ \\
\hline \multicolumn{5}{|c|}{ Skill level (ref. vocational training with at most intermediate degree) } \\
\hline missing information on educational level & $-0,112$ & $-6,5$ & $-0,107$ & $-6,6$ \\
\hline no vocational training with at most intermediate degree & $-0,208$ & $-34,4$ & $-0,207$ & $-22,6$ \\
\hline Abitur/equivalent; with or without vocational training & 0,107 & 22,0 & 0,145 & 21,7 \\
\hline university/technical/professional college degree & 0,524 & 53,0 & 0,443 & 55,8 \\
\hline Potential experience $^{1}$ & 3,257 & 24,9 & $-0,048$ & $-0,3$ \\
\hline Potential experience squared ${ }^{1}$ & $-0,057$ & $-21,5$ & 0,007 & 1,9 \\
\hline \multicolumn{5}{|l|}{ Preceding state (ref. job-to-job) } \\
\hline first spell & $-0,172$ & $-17,3$ & $-0,187$ & $-21,4$ \\
\hline unemployed & $-0,290$ & $-59,5$ & $-0,255$ & $-52,6$ \\
\hline job followed by gap & $-0,174$ & $-33,8$ & $-0,223$ & $-44,4$ \\
\hline unemployment followed by gap & $-0,310$ & $-53,6$ & $-0,328$ & $-48,3$ \\
\hline \multicolumn{5}{|l|}{ Local labour demand (district level) } \\
\hline unemployment rate & $-0,003$ & $-2,8$ & 0,003 & 2,0 \\
\hline gdp growth & 0,000 & 1,0 & 0,000 & 0,6 \\
\hline \multicolumn{5}{|l|}{ Federal state (ref. North Rhine Westphalia) } \\
\hline Schleswig-Holstein, Hamburg & $-0,021$ & $-1,2$ & 0,018 & 0,6 \\
\hline Lower Saxony, Bremen & $-0,045$ & $-6,7$ & $-0,057$ & $-3,1$ \\
\hline Hessen & 0,015 & 0,9 & 0,045 & 1,6 \\
\hline Rhineland Palatinate, Saarland & $-0,044$ & $-4,3$ & $-0,045$ & $-2,8$ \\
\hline Baden Wurttemberg & 0,019 & 1,7 & 0,018 & 1,2 \\
\hline Bavaria & 0,007 & 0,5 & 0,037 & 1,1 \\
\hline \multicolumn{5}{|l|}{ Firm size (ref. $<19$ employees) } \\
\hline $20-49$ & 0,123 & 34,6 & 0,166 & 30,9 \\
\hline $50-249$ & 0,173 & 34,0 & 0,261 & 50,2 \\
\hline 250-999 & 0,256 & 43,3 & 0,387 & 52,2 \\
\hline 1000 and more & 0,354 & 34,8 & 0,499 & 35,6 \\
\hline \multicolumn{5}{|l|}{ Industry (ref. business services) } \\
\hline agriculture, mining & $-0,197$ & $-11,7$ & $-0,136$ & $-6,2$ \\
\hline energy, traffic and information & $-0,121$ & $-8,4$ & 0,004 & 0,2 \\
\hline manufacturing & 0,009 & 1,0 & $-0,025$ & $-2,1$ \\
\hline construction & 0,012 & 1,0 & $-0,168$ & $-8,6$ \\
\hline trade and retail & $-0,034$ & $-3,7$ & $-0,054$ & $-4,3$ \\
\hline personal and domestic services & $-0,342$ & $-28,8$ & $-0,238$ & $-19,7$ \\
\hline social and public services & $-0,154$ & $-12,2$ & $-0,002$ & $-0,1$ \\
\hline temporary work agency & $-0,530$ & $-42,1$ & $-0,387$ & $-30,1$ \\
\hline Foreigner & $-0,122$ & $-23,1$ & $-0,053$ & $-6,2$ \\
\hline Constant & 4,078 & 267,1 & 3,990 & 195,3 \\
\hline $\log ($ sigma $)$ & $-0,878$ & $-64,7$ & $-0,713$ & $-93,7$ \\
\hline Wald chi'2(33) & 50.486 & & 48.667 & \\
\hline Log pseudolikelihood & -102.446 & & -71.252 & \\
\hline Number of obs. & 178.022 & & 99.163 & \\
\hline Censored obs. & 17.274 & & 2.801 & \\
\hline
\end{tabular}

The standard errors of the coefficients are adjusted for 325 regional clusters.

${ }^{1}$ The coefficients of the experience variables are multiplied by 100 in order to obtain legible values.

Source: IEB, Federal Statistical Office, own calculations. 
started jobs. Wages in the next job after unemployment are about 26 to 33 percent lower than wages of persons changing directly from job-to-job. The local unemployment rate has a negative effect on men's wages and an (unexpected) opposite effect on women's wages. The effects of the federal states' variables are often insignificant, with persons from Lower Saxony/Bremen and Rhineland Palatinate/Saarland having significantly lower wages than those from the reference North Rhine Westphalia.

Firm size is positively correlated with wages: larger firms pay higher wages. This effect seems to be stronger for women. In most industries, wages are lower than in business services, which is the reference group. Especially workers in personal and domestic services as well as temporary agency workers are worse off.

Summarizing, the multivariate models in this section have demonstrated the influence of various individual, regional and employer characteristics on our central variables of interest, tenure and wages in new jobs. Apart from the influence of these covariates, the results confirmed that durations of new jobs did not decrease ceteris paribus, while there were real wage losses during the reform period and even stronger wage losses in the recession period following the Hartz reforms.

\subsection{Job durations and wages for selected groups of workers}

While the analysis of the last section has already shown that certain worker characteristics are unfavorable for the chance to get a good job in terms of longer tenure and a higher wage, it is not clear how the situation of more disadvantaged groups of workers has changed during the reform period and thereafter. This question is now examined separately by looking at changes of our job quality indicators across periods for three selected groups: temporary agency workers, workers who were unemployed before taking up a new job and unskilled workers.

\subsubsection{Job durations for selected groups}

While the model analysis in section 5.2 already showed that overall job durations did not decrease, this is not necessarily the case for everybody. We turn back to the descriptive approach of section 5.1 to check whether our selected groups have experienced a loss in job stability in the periods during or after the Hartz reforms.

Graph 7 shows Kaplan-Meier survivor functions across periods for the whole sample (first panel) and for the groups of temporary agency workers, unskilled workers and previously unemployed workers. It is obvious that there is virtually no effect on job durations for these groups over time. Comparing the three groups with the survivor function for the whole sample, 
Graph 7: Survivor Functions for Different Groups, West Germany, 1998-2002, 2003-2005 and 2005-2009, by Gender

Men

All

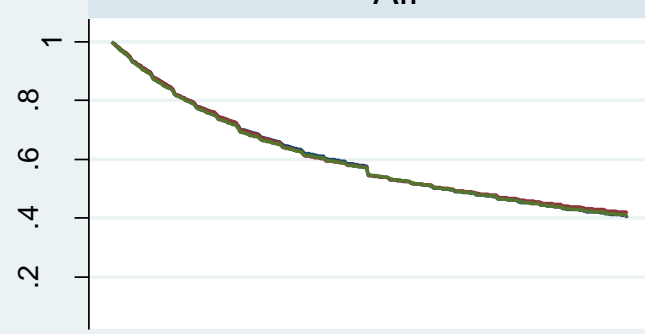

Temporary Agency Work

Unskilled
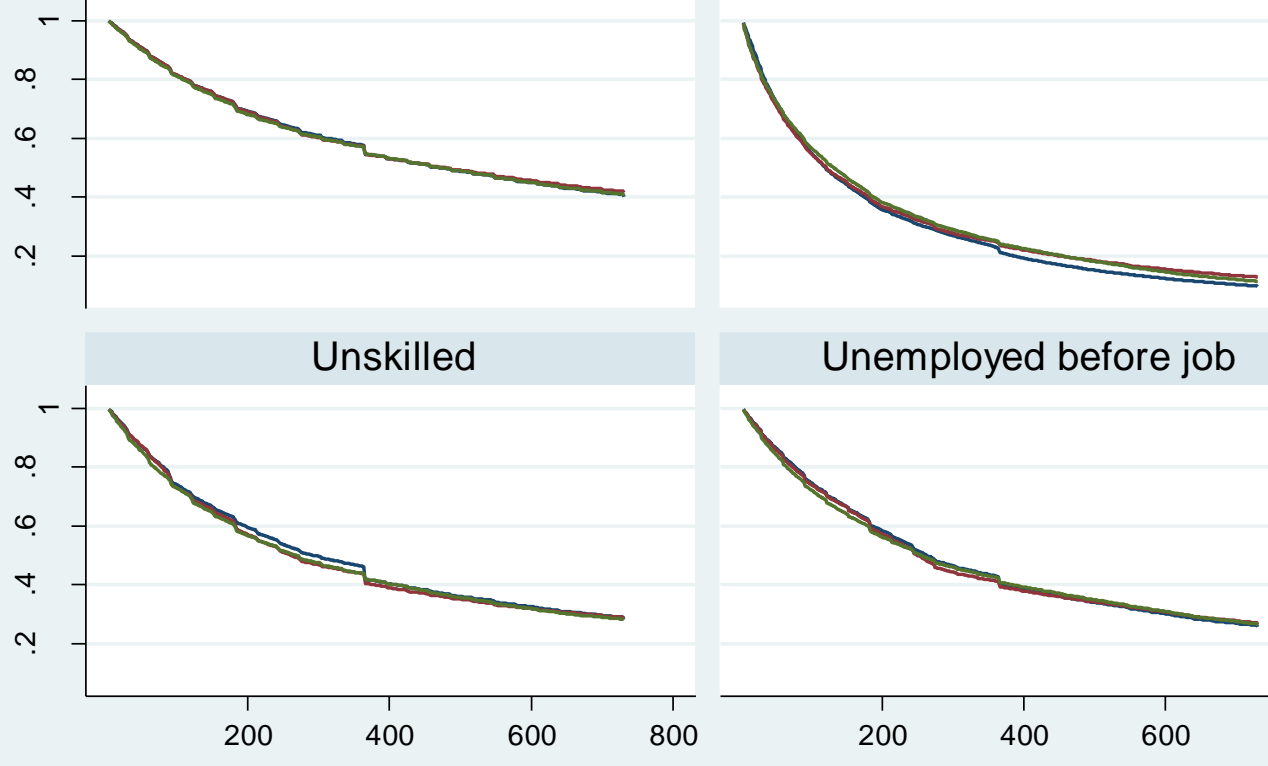

Unemployed before job

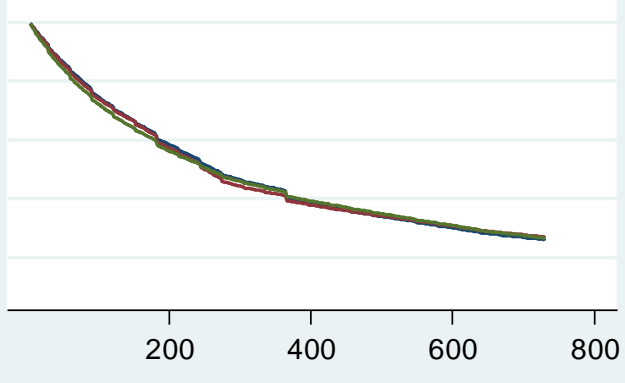

Days

\begin{tabular}{|c|c|}
\hline 02 & - 2003-2005 \\
\hline
\end{tabular}

\section{Women}

All

Temporary Agency Work

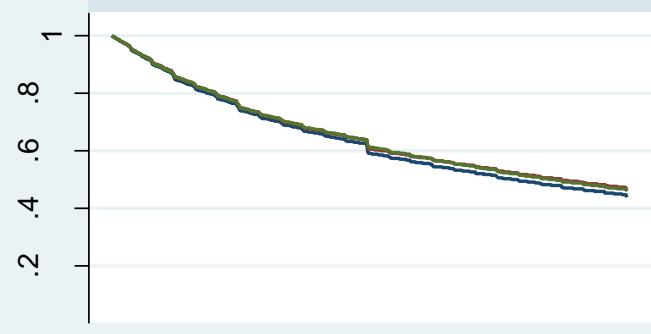

Unskilled

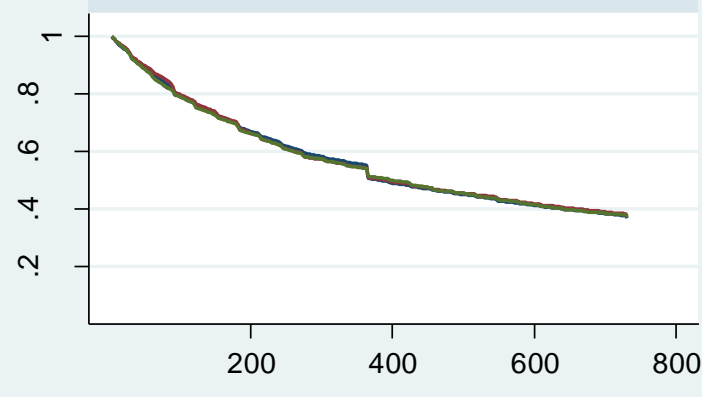

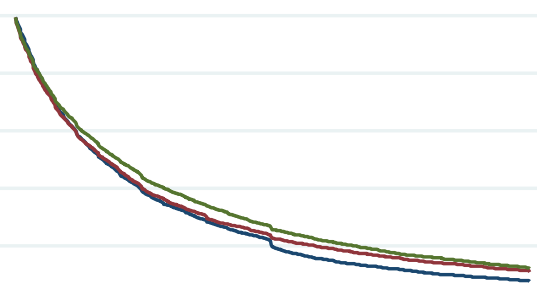

Unemployed before job

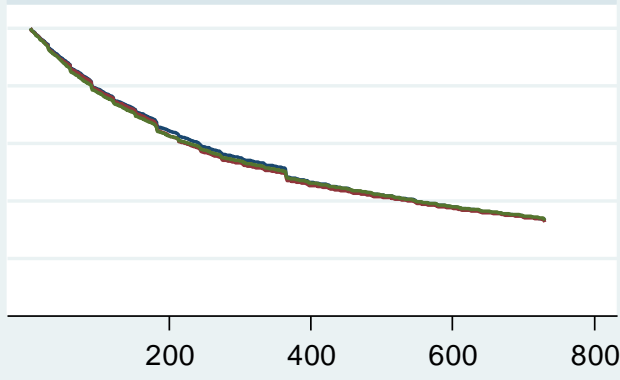

$-1998-2002 \quad 2003-2005 \quad 2006-2009$

Source: IEB, own calculations, $\mathrm{N}=832.158$. 
the lower level of job stability for the selected groups and especially for temporary agency workers is confirmed. ${ }^{8}$

\subsubsection{Wages for selected groups}

Table 3 presents median log wages together with changes across time periods for the whole sample and for the three selected groups of workers. The model analysis in section 5.2.2. clearly proved these groups to have lower wages ceteris paribus and the median wages add to this finding. The differences in the median wages between periods can be roughly interpreted as percentage changes. For men, the total median wage dropped by 3 percent from the first to the second period and declined further by 9 percent from the second to the third period. For women, the decline between the first two periods is also of about 3 percent and the decline

Table 3: Differences (log points) in Observed Median Wages for Different Groups across Periods, by Gender

\begin{tabular}{llccccc} 
& & \multicolumn{3}{c}{ Log Median Wage } & \multicolumn{2}{c}{ Differences } \\
& & $\mathbf{1 9 9 8 - 2 0 0 2}$ & $\mathbf{2 0 0 3 - 2 0 0 5}$ & $\mathbf{2 0 0 6 - 2 0 1 0}$ & $\mathbf{0 3 / 0 5 - 9 8 / 0 2}$ & $\mathbf{0 6 / 1 0 - 0 3 / 0 5}$ \\
\hline Men & All & 4,36 & 4,33 & 4,24 & $-0,03$ & $-0,09$ \\
& Temporary & 3,81 & 3,75 & 3,71 & $-0,06$ & $-0,04$ \\
& Unskilled & 4,03 & 3,95 & 3,84 & $-0,08$ & $-0,12$ \\
& Unempl. before & 4,19 & 4,16 & 4,05 & $-0,03$ & $-0,12$ \\
\hline \multirow{2}{*}{ Women } & All & 4,14 & 4,11 & 4,06 & $-0,03$ & $-0,04$ \\
& Temporary & 3,75 & 3,64 & 3,63 & $-0,11$ & $-0,01$ \\
& Unskilled & 3,83 & 3,77 & 3,69 & $-0,06$ & $-0,08$ \\
& Unempl. before & 3,99 & 3,93 & 3,87 & $-0,06$ & $-0,06$
\end{tabular}

Source: IEB, own calculations, N=761.246.

between the second and the third period is about 4 percent. Representing the group with the lowest median wage, temporary workers experienced strong wage losses between the first two periods with a drop in the median wage of about 6 percent for men and about 11 percent for females. Unskilled workers as a group clearly suffer the strongest wages losses: for men, the median wage falls by about 8 percent between the first two periods and by another 12 percent between the second and the third period. The median wage of female unskilled workers falls by about 6 percent from the first to the second and by about 8 percent between the second and the third period. For men who were unemployed before the job, there is again a very strong decline in the median wage of about 12 percent between the last two periods. For the group of women taking up a job after unemployment, the drop in the median wage is about 6 percent both

\footnotetext{
8 We also tried to assess the group-period changes in job durations by means of an interacted model, see Table A-5 in the appendix. The interactions of groups and periods turned out to be often insignificant, thus corresponding to the graphical results presented here.
} 
between the first two and between the last two periods. Summarizing, median wage losses were often stronger in the three selected groups, compared to the overall wage trends. ${ }^{9}$

\section{Conclusion}

We study the quality of newly started jobs in the period from 1998 to 2010 in West Germany, using job duration and wages as indicators of job quality. In the period from 2003 to 2005, the most severe labour market reforms in Germany's post war history, the so called Hartz reforms, were implemented. Because of the profound changes in the unemployment benefit system brought about in 2005, a reduction in reservation wages leading to lower wages especially for new jobs was expected. Furthermore, we expected a tendency towards shorter employment durations because of the deregulative elements of the Hartz reforms, aimed at increasing flexibility in the labour market. In short, we hypothesized that a lower quality especially for new jobs had been one of the factors explaining the relatively small decrease in employment which occurred during the "great recession" in the years 2008/2009, also known as Germany's "employment miracle".

The introductory discussion of the macro-performance of the German labour market confirmed the positive trends in employment and unemployment after the Hartz reforms. We also presented evidence of an (unexpected) overall decrease in labour turnover in recent years.

A large administrative individual data set was then used to study changes in the distributions of job tenures and wages over time. The effects of different time periods on our job quality indicators were assessed in multivariate models controlling for a range of individual, firm and regional characteristics. Although the data used are attractive because of their size and representative for employment liable to social insurance contributions, there are some relevant drawbacks: we confine the wage analysis to fulltime employees and also have no information on wages beyond the social security threshold. Moreover, mini-jobs, self-employed, civil servants and persons no longer searching for a job are not contained in our analysis. We also do not observe whether employment contracts are fixed-term or open-ended. Hence our findings are based on a large and important part of the workforce, but not on all workers.

The descriptive micro-data results on job tenure point to overall stable job durations for men and to somewhat longer durations for women. Interestingly, the graphical analysis did not show a clear tendency towards a more unequal distribution of job tenures. Consistent with the finding of a decrease in labour turnover, the model analysis pointed to even somewhat longer job tenures in the reform period. When looking at selected groups of workers who might be

9 When we tried to detect these combined group-period-effects by including interaction terms in our wage model (table A-6 in the appendix), the coefficients were however often rather small and insignificant. 
expected to be found in unstable employment with a higher probability, we also found no evidence of a decrease in job stability over time.

The analysis of the wage distributions, on the other hand, shows both a decrease in real wages over time and an increase in overall wage dispersion. The wage models showed stronger wage losses in the period 2006-2009, as compared to the reform period 2003-2005. Looking at selected groups of workers, evidence is found that the disadvantaged groups suffered from disproportionate wage losses.

Trying to summarize our findings on the background of our research question, the labour market reforms in Germany do not seem to have had a strong influence on job durations. The observed high level of job stability might be interpreted as an unintended side effect of the reforms: people are more reluctant to quit both because of the benefit system being less generous than before and because of lower entry wages over time. With respect to wages, the decline in reservation wages brought about by the Hartz reforms has conceivably reinforced an already existing tendency towards lower wages and greater wage inequality, with workers in the lower part of the wage distribution suffering most. 


\section{References}

Antoni, M.; Jahn, E. J. (2009): Do changes in regulation affect employment duration in temporary help agencies? Industrial and Labor Relations Review, Vol. 62 (2), 226-251.

Arent, S.; Nagl, W. (2011): Unemployment benefit and wages: The Impact of the Labor Market Reform in Germany on (reservation) wages. Ifo Working Paper No. 101, June 2011.

Bergemann, A.; Mertens, A (2011), Job Stability Trends, Lay-offs, and Transitions to Unemployment in West Germany. Labour: Review of Labour Economics and Industrial Relations, Vol. 25 (4), 421-446.

Blossfeld, H.-P.; Golsch, K.; Rohwer, G. (2007): Event History Analysis With Stata, Mahwah: Erlbaum.

Boockmann, B.; Steffes, S. (2010): Workers, Firms, or Institutions: What Determines Job Duration for Male Employees in Germany? Industrial and Labor Relations Review, Vol. 64 (1), 109-127.

Boockmann, B.; Steffes, S. (2011): Heterogenität der Beschäftigungsdynamik und Segmentierungsphänomene auf dem deutschen Arbeitsmarkt, Journal for Labour Market Research, Vol. 44, 103-109.

Boeri, T. (2011): Institutional Reforms and Dualism in European Labor Markets. Handbook of Labor Economics, Vol. 4B, 1173-1236, Elsevier.

Burda, M.; Hunt, J. (2011), What Explains the German Labor Market Miracle in the Great Recession? Brookings Papers on Economic Activity, 273-319.

Cameron, A. C.; Trivedi, P. K. (2005): Microeconometrics: Methods and Applications, Cambridge University Press, New York.

Card, D.; Heining, J.; Kline, P. (2013): Workplace heterogeneity and the rise of West German wage inequality, The Quarterly Journal of Economics, Vol. 128 (3), 967-1015.

Dorner, M.; Heining, J.; Jacobebbinghaus, P.; Seth, S. (2010): Sample of Integrated Labour Market Biographies (SIAB) 1975-2008. (FDZ Datenreport, 01/2010 (en)), Nürnberg, auch als: (2010) The Sample of Integrated Labour Market Biographies, Schmollers Jahrbuch, Vol. 130 (4), 599-608.

Dustmann, Ch.; Ludsteck, J.; Schönberg, U. (2009): Revisiting the German Wage Structure, The Quarterly Journal of Economics, 124 (2): 843-881.

Eberle, J.; Jacobebbinghaus, P.; Ludsteck, J.; Witter, J. (2011): Generation of time-consistent industry codes in the face of classification changes. Simple heuristic based on the Establishment History Panel (BHP). FDZ Methodenreport, 05/2011.

Fahr, R.; Sunde, U. (2009): Did the Hartz Reforms Speed-Up the Matching Process? A MacroEvaluation Using Empirical Matching Functions. German Economic Review, Vol. 10 (3), 284-316.

Fitzenberger, B.; Garloff, A. (2007): Labor market transitions and the wage structure in Germany. Jahrbücher für Nationalökonomie und Statistik, Vol. 227 (2), 115-152. 
Fitzenberger, B.; Wilke, R.A. (2010): New Insights into Unemployment Duration and Post Unemployment Earnings in Germany. Oxford Bulletin of Economics and Statistics, Vol. 72 (6), 794-826.

Gartner, H.; Merkl, Ch. (2011): The roots of the German miracle. VoxEU.org, 09.03.2011.

Giannelli, G. C.; Jaenichen, U.; Villosio, C. (2012): Have labor market reforms at the turn of the millennium changed the job and employment durations of new entrants? A comparative study for Germany and Italy. Journal of Labor Research, Vol. 33 (2), 143-172.

Jacobebbinghaus, P.; Seth, S. (2007): The German integrated employment biographies sample IEBS. Schmollers Jahrbuch. Zeitschrift für Wirtschafts- und Sozialwissenschaften, Vol. 127 (2), 335-342.

Jacobi, L.; Kluve, J. (2007): Before and After the Hartz Reforms: The Performance of Active Labour Market Policy in Germany. Journal of Labour Market Research, Vol. 40 (1), 45-64.

Jahn, E. J.; Riphahn, R. T.; Schnabel, C. (2012): Feature: Flexible forms of employment. Boon and bane. The Economic Journal, Vol. 122, No. 562.

Kahn, L. (2008): Job Duration, Match Quality and the Business Cycle: What We Can Learn from Firm Fixed Effects, mimeo.

Klinger, S.; Rothe, Th. (2012): The impact of labour market reforms and economic performance on the matching of the short-term and the long-term unemployed. Scottish Journal of Political Economy, Vol. 59 (1), 90-114.

Konle-Seidl, R.; Trübswetter, P. (2011): Dynamik auf den europäischen Arbeitsmärkten: Sind unsichere Verträge der Preis für mehr Beschäftigung? IAB-Kurzbericht, 25/2011.

Machin, S.; Manning, A. (1999): The causes and consequences of long-term unemployment in Europe. Handbook of Labor Economics, Vol. 3C, 3085-3139, Elsevier.

Möller, J. (2010): The German labor market response in the world recession. De-mystifying a miracle. Zeitschrift für ArbeitsmarktForschung, Vol. 42 (4), 325-336.

Rebien, M.; Kettner, A. (2011): Die Konzessionsbereitschaft von arbeitslosen Bewerbern und Beschäftigten nach den Hartz-Reformen. In: WSI-Mitteilungen, Vol. 64 (5), 218-225.

Riphahn, R. T.; Schnitzlein, D. D. (2011), Wage Mobility in East and West Germany, IZA Discussion Paper No. 6246.

Schaffner, S. (2011): Heterogeneity in the cyclical sensitivity of job-to-job flows. Journal of Labour Market Research, Vol. 43 (4), 263-275.

Wichert, L.; Wilke, R. A. (2012), Which factors safeguard employment?: an analysis with misclassified German register data. Journal of the Royal Statistical Society 175, Part1, 135-151. 


\section{Appendix}

Table A-1: Survival Probabilities by Gender after 6, 12, 18 and 24 months of Tenure, West Germany 1998-2009, by Gender

\begin{tabular}{cccccrccc}
\multicolumn{9}{c}{ Men } \\
Year & 6 mths & 12 mths & 18 mths & 24 mths & 6 mths & 12 mths & 18 mths & 24 mths \\
\hline 1998 & 0,72 & 0,56 & 0,49 & 0,42 & 0,75 & 0,60 & 0,51 & 0,44 \\
1999 & 0,71 & 0,56 & 0,47 & 0,41 & 0,76 & 0,62 & 0,52 & 0,46 \\
2000 & 0,70 & 0,55 & 0,46 & 0,39 & 0,73 & 0,59 & 0,49 & 0,42 \\
2001 & 0,71 & 0,55 & 0,47 & 0,39 & 0,75 & 0,59 & 0,51 & 0,44 \\
2002 & 0,70 & 0,54 & 0,46 & 0,40 & 0,74 & 0,59 & 0,51 & 0,45 \\
2003 & 0,71 & 0,56 & 0,47 & 0,41 & 0,76 & 0,62 & 0,53 & 0,46 \\
2004 & 0,71 & 0,55 & 0,47 & 0,41 & 0,75 & 0,62 & 0,53 & 0,46 \\
2005 & 0,71 & 0,55 & 0,48 & 0,42 & 0,76 & 0,62 & 0,54 & 0,47 \\
2006 & 0,70 & 0,55 & 0,47 & 0,40 & 0,75 & 0,62 & 0,53 & 0,46 \\
2007 & 0,70 & 0,57 & 0,47 & 0,41 & 0,75 & 0,62 & 0,53 & 0,46 \\
2008 & 0,70 & 0,55 & 0,47 & 0,41 & 0,76 & 0,62 & 0,53 & 0,46 \\
2009 & 0,70 & 0,54 & 0,46 & 0,40 & 0,76 & 0,61 & 0,53 & 0,44
\end{tabular}

Table A-2: Survival Probabilities after 12 Months of Tenure, West Germany 1998-2009, by Gender, Age and Skill

\begin{tabular}{cccccccc} 
Year & Age & Unskilled & Skilled & $\begin{array}{c}\text { High- } \\
\text { Skilled }\end{array}$ & Unskilled & Skilled & $\begin{array}{c}\text { High- } \\
\text { Skilled }\end{array}$ \\
\hline 1998 & $25-34$ & 0,40 & 0,52 & 0,73 & 0,44 & 0,58 & 0,66 \\
1999 & $25-34$ & 0,41 & 0,52 & 0,72 & 0,49 & 0,60 & 0,64 \\
2000 & $25-34$ & 0,37 & 0,52 & 0,71 & 0,43 & 0,57 & 0,60 \\
2001 & $25-34$ & 0,37 & 0,52 & 0,71 & 0,43 & 0,58 & 0,63 \\
2002 & $25-34$ & 0,35 & 0,49 & 0,70 & 0,43 & 0,58 & 0,62 \\
2003 & $25-34$ & 0,39 & 0,51 & 0,73 & 0,48 & 0,61 & 0,66 \\
2004 & $25-34$ & 0,37 & 0,51 & 0,73 & 0,46 & 0,60 & 0,63 \\
2005 & $25-34$ & 0,36 & 0,50 & 0,72 & 0,44 & 0,59 & 0,64 \\
2006 & $25-34$ & 0,37 & 0,50 & 0,73 & 0,46 & 0,59 & 0,68 \\
2007 & $25-34$ & 0,39 & 0,52 & 0,74 & 0,46 & 0,59 & 0,69 \\
2008 & $25-34$ & 0,36 & 0,50 & 0,75 & 0,47 & 0,59 & 0,70 \\
2009 & $25-34$ & 0,40 & 0,50 & 0,70 & 0,49 & 0,59 & 0,67 \\
\hline 1998 & $35-54$ & 0,47 & 0,57 & 0,75 & 0,56 & 0,62 & 0,70 \\
1999 & $35-54$ & 0,52 & 0,57 & 0,72 & 0,60 & 0,64 & 0,68 \\
2000 & $35-54$ & 0,52 & 0,57 & 0,72 & 0,54 & 0,61 & 0,64 \\
2001 & $35-54$ & 0,47 & 0,56 & 0,72 & 0,53 & 0,61 & 0,67 \\
2002 & $35-54$ & 0,46 & 0,55 & 0,69 & 0,51 & 0,61 & 0,67 \\
2003 & $35-54$ & 0,49 & 0,57 & 0,73 & 0,54 & 0,64 & 0,69 \\
2004 & $35-54$ & 0,45 & 0,56 & 0,73 & 0,55 & 0,64 & 0,69 \\
2005 & $35-54$ & 0,45 & 0,55 & 0,71 & 0,54 & 0,65 & 0,69 \\
2006 & $35-54$ & 0,46 & 0,55 & 0,72 & 0,56 & 0,63 & 0,67 \\
2007 & $35-54$ & 0,48 & 0,57 & 0,73 & 0,55 & 0,64 & 0,69 \\
2008 & $35-54$ & 0,44 & 0,55 & 0,72 & 0,51 & 0,64 & 0,71 \\
2009 & $35-54$ & 0,45 & 0,54 & 0,71 & 0,52 & 0,63 & 0,68
\end{tabular}


Table A-3: Percentiles of the Wage Distribution and Changes, West Germany 1998 and 2010, by Gender

\begin{tabular}{|c|c|c|c|c|c|c|}
\hline \multirow[t]{2}{*}{ Percentiles } & \multicolumn{3}{|c|}{1998} & \multicolumn{3}{|c|}{2010} \\
\hline & $\begin{array}{r}25 \text { th } \\
\text { percentile }\end{array}$ & $\begin{array}{r}50 \text { th } \\
\text { percentile }\end{array}$ & $\begin{array}{r}75 \text { th } \\
\text { percentile }\end{array}$ & $\begin{array}{r}25 \text { th } \\
\text { percentile }\end{array}$ & $\begin{array}{r}50 \text { th } \\
\text { percentile }\end{array}$ & $\begin{array}{r}75 \text { th } \\
\text { percentile }\end{array}$ \\
\hline Men & 4,09 & 4,36 & 4,66 & 3,84 & 4,19 & 4,55 \\
\hline Women & 3,78 & 4,13 & 4,45 & 3,66 & 4,05 & 4,44 \\
\hline \multirow[t]{2}{*}{ Differences (log points) } & \multicolumn{2}{|c|}{1998} & \multicolumn{2}{|c|}{2010} & 2010-1998 & 2010-1998 \\
\hline & 50th-25th $\mathrm{p}$. & 75th-50th p. & 50th-25th p. & 75th-50th p. & 50th-25th p. & 75th-50th $\mathrm{p}$. \\
\hline Men & 0,27 & 0,30 & 0,35 & 0,36 & 0,08 & 0,06 \\
\hline Women & 0,35 & 0,32 & 0,39 & 0,39 & 0,04 & 0,06 \\
\hline
\end{tabular}

Table A-4: Percentiles of the Wage Distribution and Changes, West Germany 1998 and 2010, by Gender, Age and Skill

\begin{tabular}{|c|c|c|c|c|c|c|c|}
\hline \multicolumn{2}{|c|}{ Percentiles } & \multicolumn{3}{|c|}{1998} & \multicolumn{3}{|c|}{2010} \\
\hline Men & & $\begin{array}{c}25 \text { th } \\
\text { percentile }\end{array}$ & $\begin{array}{c}\text { 50th } \\
\text { percentile }\end{array}$ & $\begin{array}{c}\text { 75th } \\
\text { percentile }\end{array}$ & $\begin{array}{c}25 \text { th } \\
\text { percentile }\end{array}$ & $\begin{array}{c}50 \text { th } \\
\text { percentile }\end{array}$ & $\begin{array}{c}75 \text { th } \\
\text { percentile }\end{array}$ \\
\hline age $25-34$ & unskilled/miss. & 3,71 & 4,01 & 4,27 & 3,52 & 3,76 & 4,08 \\
\hline \multirow{5}{*}{ age $35-54$} & skilled & 4,06 & 4,28 & 4,49 & 3,80 & 4,09 & 4,35 \\
\hline & high-skilled & 4,54 & 4,75 & 1 & 4,36 & 4,65 & 1 \\
\hline & unskilled/miss. & 3,83 & 4,10 & 4,37 & 3,59 & 3,86 & 4,21 \\
\hline & skilled & 4,11 & 4,36 & 4,62 & 3,88 & 4,20 & 4,50 \\
\hline & high-skilled & $\begin{array}{c}4,79 \\
25 \text { th } \\
\text { percentile }\end{array}$ & $\begin{array}{c}5,04 \\
50 \text { th } \\
\text { percentile }\end{array}$ & $\begin{array}{c}1 \\
\text { 75th } \\
\text { percentile }\end{array}$ & $\begin{array}{c}4,58 \\
25 \text { th } \\
\text { percentile }\end{array}$ & $\begin{array}{c}4,98 \\
50 \text { th } \\
\text { percentile }\end{array}$ & $\begin{array}{c}1 \\
\text { 75th } \\
\text { percentile }\end{array}$ \\
\hline \multirow[t]{3}{*}{ age $25-34$} & unskilled/miss. & 3,51 & 3,83 & 4,08 & 3,33 & 3,64 & 3,93 \\
\hline & skilled & 3,82 & 4,14 & 4,40 & 3,69 & 4,03 & 4,33 \\
\hline & high-skilled & 4,31 & 4,60 & 4,83 & 4,16 & 4,49 & 1 \\
\hline \multirow[t]{3}{*}{ age $35-54$} & unskilled/miss. & 3,53 & 3,85 & 4,13 & 3,48 & 3,69 & 3,97 \\
\hline & skilled & 3,73 & 4,07 & 4,40 & 3,60 & 3,96 & 4,34 \\
\hline & high-skilled & 4,23 & 4,67 & 5,02 & 4,05 & 4,50 & 1 \\
\hline \multicolumn{2}{|c|}{ Differences ( $\log$ points) } & \multicolumn{2}{|c|}{1998} & \multicolumn{2}{|c|}{2010} & 2010-1998 & 2010-1998 \\
\hline
\end{tabular}

\begin{tabular}{llcrrrrr} 
Men & & 50th-25th p. & 75th-50th p. & 50th-25th p. & 75th-50th p. & 50th-25th p. & 75th-50th p. \\
\hline \multirow{2}{*}{ age 25-34 } & unskilled/miss. & 0,30 & 0,26 & 0,24 & 0,31 & $-0,06$ & 0,06 \\
& skilled & 0,22 & 0,20 & 0,29 & 0,26 & 0,07 & 0,05 \\
& high-skilled & 0,21 & 0,23 & 1 & 0,25 & 0,07 & 1 \\
age 35-54 & unskilled/miss. & 0,27 & 0,28 & 0,27 & 0,35 & 0,00 & 0,07 \\
& skilled & 0,25 & 0,26 & 0,32 & 0,31 & 0,06 & 0,05 \\
& high-skilled & 0,24 & 0,00 & 1 & 0,13 & 0,16 & 1 \\
Women & & 50th-25th p. & 75th-50th p. & 50th-25th p. & 75th-50th p. & 50th-25th p. & 75th-50th p. \\
\hline age 25-34 & unskilled/miss. & 0,32 & 0,24 & 0,31 & 0,28 & $-0,01$ & 0,04 \\
& skilled & 0,32 & 0,26 & 0,34 & 0,30 & 0,02 & 0,03 \\
& high-skilled & 0,30 & 0,23 & 0,33 & 0,27 & 0,03 & 0,04 \\
age 35-54 & unskilled/miss. & 0,32 & 0,28 & 0,21 & 0,28 & $-0,11$ & 0,00 \\
& skilled & 0,35 & 0,33 & 0,36 & 0,38 & 0,01 & 0,06 \\
& high-skilled & 0,44 & 0,35 & 0,44 & 0,41 & 0,00 & 0,06
\end{tabular}


Table A-5: Interacted Duration Models for West Germany, New Jobs 1998-2008, by Gender Men

Women

hazard ratio hazard ratio $\mathrm{Z}$

Duration $^{1}$

$0-31$ days

0,685

0,783

0,765

0,929

0,780

0,778

0,615

0,630

Z

hazard ratio

62-91 days

$-157,6$

0,873

0,975

$-141,6$

92-122 days

$-163,4$

0,880

$-147,7$

123-183 days

$-150,4$

$-145,8$

184-365 days

$-151,1$

1,029

$-145,7$

366-548 days

$-158,0$

$-146,0$

549-730 days

$-148,3$

$-159,1$

0,780

$-157,5$

Year of entry (ref. 1998-2002)

2003-2005

0,849

$-144,7$

$-149,2$

2006-2008

1,210

$-2,2$

0,660

(4)

Quarter of entry (ref. 1st quarter)

2nd quarter

2nd quarter * (2003-2005)

1,251

2,4

0,858

$-2,0$

1,025

0,3

1,058

13,7

1,137

1,111

8,0

1,105

2,0

1,069

3,0

1,280

3rd quarter

3 rd quarter * (2003-2005)

1,035

1,084

1,315

4th quarter

4 th quarter $*(2003-2005)$

1,094

4 th quarter * (2006-2008)

1,087

Local labour demand (district level)

unemployment rate

1,008

unemployment rate * (2003-2005)

unemployment rate * (2006-2008)

0,997

0,989

gdp growth

gdp growth * (2003-2005)

gdp growth * (2006-2008)

1,000

0,994

0,994

3,3
13,0

1,166

2,3

9,5

1,035

1,014

1,230

1,062

1,073

Federal state (ref. North Rhine Westphalia)

Schleswig-Holstein, Hamburg

Schleswig-Holstein, Hamburg * (2006-2008)

0,997

Lower Saxony, Bremen * (2003-2005)

1,141

0,984

Lower Saxony, Bremen * (2006-2008)

Hessen

0,970

0,999

Hessen * (2003-2005)

0,980

Hessen * (2006-2008)

1,000

Rhineland Palatinate, Saarland * (2003-2005)

1,031

1,029

0,900

Baden Wurttemberg

1,111

0,997

1,006

1,038

0,934

1,000

0,1

0,999

$-0,1$

0,993

0,999

0,999

0,994

$-1,4$

$-0,6$

$-1,4$

$-1,7$

$-0,1$

$-1,5$

Baden Wurttemberg * (2006-2008)

Bavaria

Bavaria * (2003-2005)

Bavaria * (2006-2008)

$\begin{array}{rr}1,9 & 1,014 \\ 0,8 & 1,018 \\ -1,5 & 1,011 \\ -0,1 & 0,998 \\ 3,3 & 0,994 \\ -0,4 & 0,982 \\ -1,1 & 0,971 \\ 0,0 & 0,936 \\ -0,5 & 0,974 \\ 0,0 & 0,934 \\ 0,6 & 0,988 \\ 0,6 & 1,080 \\ -4,1 & 0,884 \\ 2,5 & 0,971 \\ -0,1 & 1,030 \\ 0,2 & 0,921 \\ 1,0 & 0,988 \\ -1,2 & 0,975\end{array}$

0,5 
Firm size (ref. < 19 employees)

hazard ratio

20-49

$20-49 *(2003-2005)$

$20-49 *(2006-2008)$

$50-249$

$50-249 *(2003-2005)$

$50-249 *(2006-2008)$

250-999

$250-999 *(2003-2005)$

$250-999 *(2006-2008)$

1000 and more

1000 and more $*(2003-2005)$

1000 and more $*(2006-2008)$

\section{Industry (ref. business services)}

agriculture, mining

agriculture, mining * (2003-2005)

agriculture, mining * (2006-2008)

energy, traffic and information

energy, traffic and information * (2003-2005)

energy, traffic and information * (2006-2008)

manufacturing

manufacturing * (2003-2005)

manufacturing * (2006-2008)

construction

construction $*(2003-2005)$

construction $*(2006-2008)$

trade and retail

trade and retail $*(2003-2005)$

trade and retail $*(2006-2008)$

personal and domestic services

personal and domestic services * (2003-2005)

personal and domestic services * (2006-2008)

social and public services

social and public services $*(2003-2005)$

social and public services $*(2006-2008)$

temporary work agency

temporary work agency $*(2003-2005)$

temporary work agency $*(2006-2008)$

\section{Foreigner}

Foreigner * (2003-2005)

Foreigner * (2006-2008)

Age (ref. 30-34)

age $25-29$

age $25-29 *(2003-2005)$

age $25-29 *(2006-2008)$

age $35-39$

age $35-39 *(2003-2005)$

age $35-39 *(2006-2008)$

age $40-44$

age $40-44 *(2003-2005)$

age 40-44* (2006-2008)

age 45-49

age $45-49 *(2003-2005)$

age 45-49* (2006-2008)

\begin{tabular}{|c|c|c|c|}
\hline 0,821 & $-10,0$ & 0,993 & $-0,4$ \\
\hline 0,985 & $-0,4$ & 0,988 & $-0,3$ \\
\hline 1,014 & 0,5 & 0,989 & $-0,4$ \\
\hline 0,686 & $-20,9$ & 0,916 & $-5,2$ \\
\hline 1,003 & 0,1 & 0,976 & $-0,8$ \\
\hline 1,057 & 1,7 & 0,999 & 0,0 \\
\hline 0,533 & $-24,9$ & 0,773 & $-11,4$ \\
\hline 1,015 & 0,4 & 0,998 & 0,0 \\
\hline 1,114 & 2,9 & 1,016 & 0,5 \\
\hline 0,437 & $-15,9$ & 0,670 & $-11,8$ \\
\hline 1,025 & 0,4 & 0,887 & $-2,1$ \\
\hline 1,231 & 3,1 & 0,970 & $-0,5$ \\
\hline 1,873 & 12,5 & 1,809 & 7,8 \\
\hline 1,195 & 2,2 & 1,284 & 2,0 \\
\hline 1,205 & 2,6 & 1,375 & 2,4 \\
\hline 1,147 & 3,7 & 1,038 & 1,2 \\
\hline 0,972 & $-0,5$ & 0,879 & $-1,9$ \\
\hline 0,977 & $-0,5$ & 0,946 & $-0,8$ \\
\hline 0,744 & $-9,4$ & 0,888 & $-4,1$ \\
\hline 1,091 & 1,9 & 0,967 & $-0,7$ \\
\hline 1,063 & 1,5 & 1,017 & 0,3 \\
\hline 1,231 & 6,5 & 0,841 & $-3,4$ \\
\hline 1,008 & 0,2 & 0,934 & $-0,7$ \\
\hline 0,869 & $-2,9$ & 1,021 & 0,2 \\
\hline 0,932 & $-2,2$ & 0,986 & $-0,5$ \\
\hline 0,973 & $-0,6$ & 0,948 & $-1,2$ \\
\hline 0,954 & $-1,0$ & 0,987 & $-0,3$ \\
\hline 1,393 & 8,3 & 1,323 & 9,5 \\
\hline 1,015 & 0,3 & 0,993 & $-0,2$ \\
\hline 1,041 & 0,6 & 1,003 & 0,1 \\
\hline 0,928 & $-2,4$ & 0,806 & $-9,5$ \\
\hline 1,151 & 3,0 & 1,030 & 0,9 \\
\hline 1,005 & 0,1 & 0,959 & $-1,1$ \\
\hline 4,407 & 31,6 & 4,639 & 35,3 \\
\hline 1,038 & 0,6 & 0,921 & $-1,3$ \\
\hline 1,006 & 0,1 & 0,843 & $-2,8$ \\
\hline 1,603 & 23,2 & 1,406 & 11,5 \\
\hline 1,070 & 1,9 & 1,036 & 0,7 \\
\hline 0,875 & $-3,9$ & 0,946 & $-1,5$ \\
\hline 1,080 & 4,5 & 1,189 & 9,0 \\
\hline 1,023 & 0,7 & 0,972 & $-0,8$ \\
\hline 0,961 & $-1,2$ & 0,949 & $-1,5$ \\
\hline 0,975 & $-1,5$ & 0,869 & $-6,7$ \\
\hline 0,994 & $-0,2$ & 0,981 & $-0,5$ \\
\hline 0,928 & $-2,2$ & 0,989 & $-0,3$ \\
\hline 0,904 & $-5,2$ & 0,821 & $-8,8$ \\
\hline 0,986 & $-0,4$ & 1,016 & 0,4 \\
\hline 1,019 & 0,5 & 1,046 & 1,1 \\
\hline 0,939 & $-2,6$ & 0,824 & $-7,4$ \\
\hline 0,922 & $-2,2$ & 0,957 & $-1,0$ \\
\hline 0,939 & $-1,5$ & 1,060 & 1,5 \\
\hline
\end{tabular}


age 50-54

age $50-54 *(2003-2005)$

age $50-54 *(2006-2008)$

hazard ratio

\begin{tabular}{rrrr}
0,934 & \multicolumn{1}{c}{ Z } & Z \\
1,019 & $-3,1$ & 0,856 & $-5,9$ \\
0,861 & 0,4 & 0,971 & $-0,6$ \\
& $-3,5$ & 0,948 & $-1,1$
\end{tabular}

no degree/ no information on educational level

no degree/ no information on educ. level * (2003-2005)

no degree/ no information on educ. level * (2006-2008)

no vocational training with at most intermediate degree

no voc. train. with at most interm. degree * (2003-2005)

no voc. train. with at most interm. degree * (2006-2008)

Abitur/equivalent; with or without vocational training

Abitur/equivalent * (2003-2005)

Abitur/equivalent * (2006-2008)

University/Technical/Professional College degree

University/Tech./Profess. College degree * (2003-2005)

University/Tech./Profess. College degree * (2006-2008)

\section{Preceding state (ref. job-to-job)}

first spell

first spell $*(2003-2005)$

first spell $*(2006-2008)$

unemployed

unemployed * (2003-2005)

unemployed * (2006-2008)

job followed by gap

job followed by gap * (2003-2005)

job followed by gap * (2006-2008)
1,396

0,985

0,941

1,263

1,015

0,920

1,129

0,927

0,893

0,804

1,007

0,921

1,855

0,884

1,008

2,303

0,991

0,865

1,636

0,938

0,918

1,681

0,986

0,963
8,1

$-0,2$

$-0,9$

10,8

0,4

$-2,0$

5,9

$-2,0$

$-3,4$

$-10,0$

0,2

$-2,4$

23,7

$-2,7$

0,2

41,3

$-0,3$

$-5,2$

24,4

$-2,0$

$-2,6$

21,1

$-0,3$

$-1,0$

1,348

1,101

1,045

1,243

1,054

0,967

1,057

1,019

0,997

1,070

1,000

0,920

1,545

1,032

1,108

1,797

1,147

1,055

1,358

1,099

1,066

1,427

1,162

1,075

0,958

1,003

0,994

$-1,4$

$-0,637$

Variance of frailty term $(\log \theta)$

Wald chi ${ }^{2}$

$-0,298$

2.498 .740

$-216.011$

2.293 .746

180.369
6,4

1,3

0,6

10,1

1,3

$-0,9$

2,8

0,6

$-0,1$

3,3

0,0

14,1

0,5

1,8

31,6

4,7

1,8

17,1

2,9

2, 0

15,8

3,8

2,0

$-2,7$

0,1 $-0,3$

The standard errors of the coefficients are adjusted for 325 regional clusters.

${ }^{1}$ The hazard ratios of the duration time pieces are multiplied by 1000 in order to obtain legible values.

${ }^{2}$ The time pieces have not been interacted with the period variables. 
Table A-6: Interacted Wage Models for West Germany, New Jobs 1998-2009, by Gender

\begin{tabular}{|c|c|c|c|c|}
\hline & \multicolumn{2}{|c|}{ Men } & \multicolumn{2}{|c|}{ Women } \\
\hline & coefficient & $\mathrm{z}$ & coefficient & $\mathrm{z}$ \\
\hline \multicolumn{5}{|l|}{ Year of entry (ref. 1998-2002) } \\
\hline $2003-2005$ & $-0,083$ & $-2,9$ & $-0,109$ & $-3,3$ \\
\hline 2006-2009 & $-0,265$ & $-8,5$ & $-0,159$ & $-4,7$ \\
\hline \multicolumn{5}{|l|}{ Local labour demand (district level) } \\
\hline unemployment rate & $-0,002$ & $-1,8$ & 0,003 & 1,9 \\
\hline unemployment rate $*(2003-2005)$ & $-0,004$ & $-3,9$ & $-0,003$ & $-1,3$ \\
\hline unemployment rate $*(2006-2009)$ & 0,000 & 0,2 & 0,001 & 0,4 \\
\hline gdp growth & 0,001 & 1,5 & 0,001 & 0,5 \\
\hline gdp growth $*(2003-2005)$ & $-0,001$ & $-0,9$ & 0,000 & 0,0 \\
\hline gdp growth * (2006-2009) & $-0,001$ & $-1,3$ & $-0,001$ & $-0,5$ \\
\hline \multicolumn{5}{|l|}{ Federal state (ref. North Rhine Westphalia) } \\
\hline Schleswig-Holstein, Hamburg & $-0,025$ & $-1,5$ & 0,013 & 0,4 \\
\hline Schleswig-Holstein, Hamburg * (2003-2005) & 0,014 & 1,4 & 0,018 & 1,5 \\
\hline Schleswig-Holstein, Hamburg * (2006-2009) & 0,007 & 0,9 & 0,009 & 0,5 \\
\hline Lower Saxony, Bremen & $-0,040$ & $-5,9$ & $-0,059$ & $-2,6$ \\
\hline Lower Saxony, Bremen * (2003-2005) & $-0,015$ & $-1,2$ & 0,005 & 0,3 \\
\hline Lower Saxony, Bremen * (2006-2009) & $-0,007$ & $-0,8$ & 0,002 & 0,1 \\
\hline Hessen & 0,018 & 1,2 & 0,047 & 1,7 \\
\hline Hessen * (2003-2005) & $-0,028$ & $-2,3$ & 0,012 & 0,7 \\
\hline Hessen * (2006-2009) & 0,009 & 0,8 & $-0,013$ & $-0,8$ \\
\hline Rhineland Palatinate, Saarland & $-0,046$ & $-3,6$ & $-0,054$ & $-3,3$ \\
\hline Rhineland Palatinate, Saarland * (2003-2005) & 0,011 & 0,8 & 0,013 & 0,7 \\
\hline Rhineland Palatinate, Saarland * (2006-2009) & 0,001 & 0,1 & 0,023 & 1,3 \\
\hline Baden Wurttemberg & 0,017 & 1,4 & 0,018 & 1,1 \\
\hline Baden Wurttemberg * (2003-2005) & $-0,024$ & $-2,4$ & $-0,009$ & $-0,6$ \\
\hline Baden Wurttemberg * (2006-2009) & 0,024 & 2,3 & 0,008 & 0,5 \\
\hline Bavaria & 0,001 & 0,0 & 0,033 & 1,1 \\
\hline Bavaria * (2003-2005) & $-0,002$ & $-0,1$ & 0,001 & 0,1 \\
\hline Bavaria * (2006-2009) & 0,027 & 2,3 & 0,016 & 1,1 \\
\hline \multicolumn{5}{|l|}{ Firm size (ref. $<19$ employees) } \\
\hline $20-49$ & 0,113 & 23,4 & 0,171 & 26,5 \\
\hline $20-49 *(2003-2005)$ & 0,033 & 3,5 & 0,002 & 0,1 \\
\hline $20-49 *(2006-2009)$ & 0,012 & 1,4 & $-0,021$ & $-1,8$ \\
\hline $50-249$ & 0,157 & 29,1 & 0,254 & 41,6 \\
\hline $50-249 *(2003-2005)$ & 0,038 & 4,1 & 0,021 & 1,7 \\
\hline $50-249 *(2006-2009)$ & 0,030 & 3,9 & 0,011 & 1,0 \\
\hline $250-999$ & 0,230 & 34,6 & 0,365 & 42,4 \\
\hline $250-999 *(2003-2005)$ & 0,060 & 5,4 & 0,042 & 2,9 \\
\hline $250-999 *(2006-2009)$ & 0,054 & 4,8 & 0,047 & 3,5 \\
\hline 1000 and more & 0,316 & 28,7 & 0,471 & 28,4 \\
\hline 1000 and more $*(2003-2005)$ & 0,077 & 5,8 & 0,041 & 2,2 \\
\hline 1000 and more $*(2006-2009)$ & 0,084 & 6,2 & 0,066 & 4,5 \\
\hline \multicolumn{5}{|l|}{ Industry (ref. business services) } \\
\hline agriculture, mining & $-0,179$ & $-9,9$ & $-0,158$ & $-6,2$ \\
\hline agriculture, mining $*(2003-2005)$ & $-0,016$ & $-0,7$ & $-0,005$ & $-0,1$ \\
\hline agriculture, mining $*(2006-2009)$ & $-0,050$ & $-2,7$ & 0,034 & 1,0 \\
\hline energy, traffic and information & $-0,120$ & $-7,8$ & 0,000 & 0,0 \\
\hline energy, traffic and information $*(2003-2005)$ & $-0,007$ & $-0,5$ & $-0,002$ & $-0,1$ \\
\hline energy, traffic and information * (2006-2009) & $-0,003$ & $-0,2$ & 0,012 & 0,5 \\
\hline
\end{tabular}




\begin{tabular}{|c|c|c|c|c|}
\hline \multirow[t]{2}{*}{ Continued } & \multicolumn{2}{|c|}{ Men } & \multicolumn{2}{|c|}{ Women } \\
\hline & coefficient & $\mathrm{z}$ & coefficient & $\mathrm{z}$ \\
\hline manufacturing & $-0,011$ & $-1,1$ & $-0,038$ & $-2,7$ \\
\hline manufacturing $*(2003-2005)$ & 0,017 & 1,5 & 0,032 & 1,9 \\
\hline manufacturing $*(2006-2009)$ & 0,057 & 5,4 & 0,028 & 1,6 \\
\hline construction & 0,004 & 0,3 & $-0,168$ & $-7,2$ \\
\hline construction $*(2003-2005)$ & 0,006 & 0,5 & 0,023 & 0,5 \\
\hline construction * (2006-2009) & 0,018 & 1,5 & $-0,014$ & $-0,4$ \\
\hline trade and retail & $-0,047$ & $-4,8$ & $-0,057$ & $-4,3$ \\
\hline trade and retail $*(2003-2005)$ & 0,005 & 0,4 & 0,017 & 1,1 \\
\hline trade and retail $*(2006-2009)$ & 0,039 & 3,6 & $-0,002$ & $-0,2$ \\
\hline personal and domestic services & $-0,347$ & $-21,3$ & $-0,227$ & $-17,5$ \\
\hline personal and domestic services $*(2003-2005)$ & $-0,020$ & $-1,0$ & $-0,022$ & $-1,1$ \\
\hline personal and domestic services * (2006-2009) & 0,027 & 1,3 & $-0,025$ & $-1,4$ \\
\hline social and public services & $-0,151$ & $-12,0$ & 0,006 & 0,4 \\
\hline social and public services $*(2003-2005)$ & $-0,031$ & $-2,6$ & 0,000 & 0,0 \\
\hline social and public services $*(2006-2009)$ & 0,011 & 0,9 & $-0,028$ & $-2,3$ \\
\hline temporary work agency & $-0,530$ & $-31,3$ & $-0,365$ & $-24,2$ \\
\hline temporary work agency $*(2003-2005)$ & $-0,023$ & $-1,4$ & $-0,021$ & $-1,1$ \\
\hline temporary work agency $*(2006-2009)$ & 0,022 & 1,4 & $-0,043$ & $-2,1$ \\
\hline Foreigner & $-0,110$ & $-16,7$ & $-0,038$ & $-4,6$ \\
\hline Foreigner $*(2003-2005)$ & $-0,025$ & $-2,6$ & $-0,005$ & $-0,4$ \\
\hline Foreigner * (2006-2009) & $-0,028$ & $-3,0$ & $-0,047$ & $-3,5$ \\
\hline \multicolumn{5}{|c|}{ Skill level (ref. vocational training with at most intermediate degree) } \\
\hline no degree/ no information on educational level & $-0,131$ & $-5,4$ & $-0,133$ & $-6,0$ \\
\hline no degree/ no information on educational level $*(2003-2005)$ & 0,002 & 0,1 & 0,003 & 0,1 \\
\hline no degree/ no information on educational level $*(2006-2009)$ & 0,056 & 2,0 & 0,067 & 2,3 \\
\hline no vocational training with at most intermediate degree & $-0,208$ & $-30,6$ & $-0,201$ & $-24,1$ \\
\hline no voc. train. with at most intermediate degree $*(2003-2005)$ & 0,004 & 0,4 & $-0,003$ & $-0,2$ \\
\hline no voc. train. with at most intermediate degree $*(2006-2009)$ & 0,006 & 0,6 & $-0,010$ & $-0,7$ \\
\hline Abitur/equivalent; with or without vocational training & 0,103 & 19,7 & 0,144 & 15,9 \\
\hline Abitur/equivalent $*(2003-2005)$ & $-0,004$ & $-0,4$ & $-0,003$ & $-0,3$ \\
\hline Abitur/equivalent * (2006-2009) & 0,016 & 1,9 & 0,005 & 0,5 \\
\hline University/Technical/Professional College degree & 0,520 & 56,9 & 0,443 & 49,3 \\
\hline University/Technical/Professional College degree $*(2003-2005)$ & $-0,007$ & $-0,9$ & $-0,018$ & $-1,1$ \\
\hline University/Technical/Professional College degree * (2006-2009) & 0,015 & 1,5 & 0,011 & 0,9 \\
\hline \multicolumn{5}{|l|}{ Preceding state (ref. job-to-job) } \\
\hline first spell & $-0,205$ & $-21,1$ & $-0,228$ & $-19,7$ \\
\hline first spell * $(2003-2005)$ & 0,012 & 0,7 & 0,043 & 2,0 \\
\hline first spell * $(2006-2009)$ & 0,098 & 5,5 & 0,110 & 5,4 \\
\hline unemployed & $-0,285$ & $-53,5$ & $-0,253$ & $-44,6$ \\
\hline unemployed $*(2003-2005)$ & $-0,011$ & $-1,6$ & $-0,007$ & $-0,7$ \\
\hline unemployed $*(2006-2009)$ & $-0,012$ & $-2,1$ & $-0,001$ & $-0,2$ \\
\hline job followed by gap & $-0,165$ & $-26,7$ & $-0,234$ & $-36,6$ \\
\hline job followed by gap * $(2003-2005)$ & $-0,044$ & $-4,9$ & $-0,005$ & $-0,5$ \\
\hline job followed by gap * $(2006-2009)$ & 0,000 & 0,0 & 0,040 & 3,6 \\
\hline unemployment followed by gap & $-0,301$ & $-43,0$ & $-0,339$ & $-37,6$ \\
\hline unemployment followed by gap $*(2003-2005)$ & $-0,036$ & $-2,9$ & $-0,006$ & $-0,4$ \\
\hline unemployment followed by gap $*(2006-2009)$ & $-0,002$ & $-0,2$ & 0,042 & 2,6 \\
\hline
\end{tabular}




\begin{tabular}{|c|c|c|c|c|}
\hline \multirow[t]{2}{*}{ Continued } & \multicolumn{2}{|c|}{ Men } & \multicolumn{2}{|c|}{ Women } \\
\hline & coefficient & $\mathrm{z}$ & coefficient & $\mathrm{z}$ \\
\hline potential experience $^{1}$ & 2,680 & 23,9 & $-0,231$ & $-1,4$ \\
\hline potential experience $*(2003-2005)^{1}$ & 1,006 & 5,8 & 0,684 & 3,3 \\
\hline potential experience $*(2006-2009)^{1}$ & 1,108 & 5,7 & 0,133 & 0,7 \\
\hline potential experience squared ${ }^{1}$ & $-0,045$ & $-19,5$ & 0,008 & 2,3 \\
\hline potential experience squared $*(2003-2005)^{1}$ & $-0,022$ & $-5,5$ & $-0,011$ & $-2,2$ \\
\hline potential experience squared $*(2006-2009)^{1}$ & $-0,022$ & $-5,0$ & 0,002 & 0,5 \\
\hline Constant & 4,146 & 253,1 & 4,026 & 161,1 \\
\hline $\log (\operatorname{sigma})$ & $-0,880$ & $-65,1$ & $-0,714$ & $-94,3$ \\
\hline Wald chi' ${ }^{2}$ & 75.883 & & 84.006 & \\
\hline Log pseudolikelihood & -102.088 & & -71.122 & \\
\hline Number of obs. & 178.022 & & 99.163 & \\
\hline Censored obs. & 17.274 & & 2.801 & \\
\hline
\end{tabular}

The standard errors of the coefficients are adjusted for 325 regional clusters.

${ }^{1}$ The coefficients of the experience variables are multiplied by 100 in order to obtain legible values. 